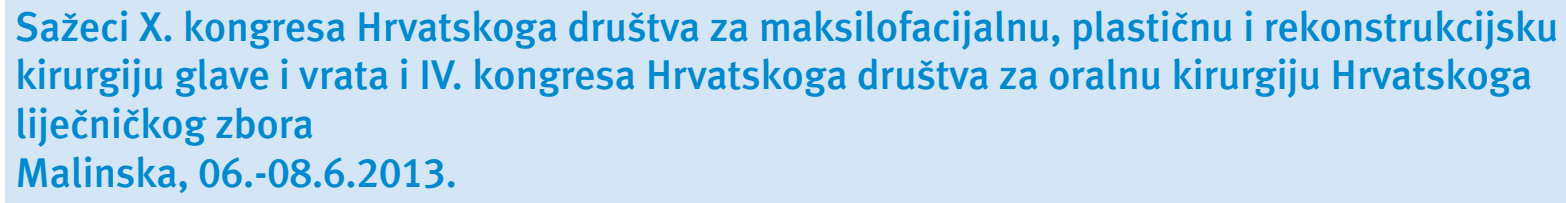

\section{UVODNA PREDAVANJA}

11 OPSKRBA MAKSILOFACIJALNE TRAUME PREMA SMJERNICAMA ETC/ERC (EUROPEAN TRAUMA COURSE / EUROPEAN RESUSCITATION COUNCIL)

Alen Protić

Zavod za hitnu medicine, KBC Rijeka, Medicinski fakultet, Sveučilišste u Rijeci

Ciljevi predavanja: Važnost opskrbe dišnog puta u maksilofacijalnim ozljedama, Odnos ozljeda lica i vratne kralježnice, Postupci pri većim krvarenjima regije glave i vrata. Uvod: Nasilje među ljudima kao uzrok maksilofacijalnih ozljeda čak i u razvijenim zemljama nalazi se na prvom mjestu ispred prometnih nesreća. Oko $50 \%$ žrtava nasilja ima povišenu razinu alkohola u krvi. U takvim slučajevima uglavnom se radi o izoliranim ozljedama pojedinačnih kostiju lica kao što su: zigomatična kost, nosne kosti, mandibula. Teže ozljede maksile, etmoida i sl. karakterističnije su ipak za promtne nesreće i padove na lice koje su često udružene s ozljedama abdomena i toraksa. Procjena i postupanje: Obuhvaća sve postupke koji se čine u prva 2 sata do dolaska tima za konačnu opskrbu maksilofacijalne traume i ne smije biti namjera da se prije dolaska tog tima finalno zbrinjavaju teže maksilofacijalne ozljede. Primarna procjena i resuscitacija: Primarna procjena predvida otkriti i odmah liječiti po život opasne ozljede. Tijekom primarne procjene nije nužno precizno definirati dijagnozu ozljede lica, već se tim mora koncentrirati na životno ugrožavajuće situacije kao što je opstrukcija dišnog puta. $A$ irway - dišni put s kontrolom vratne kralježnice, $B$ reathing - disanje i ventilacija, $C$ irculation - cirkulacija i kontrola krvarenja, $D$ ysfunction - poremé́aji CNS-a, E xposure - otkrivanje cijelog tijela. Dišni put $i$ kontrola vratne kralježnice: Opstrukcija dišnog puta je najč̌čći uzrok smrti pri maksilofacijalnim ozljedama. Dišni put pri navedenim ozljedama mora se odmah provjeriti pokušavjući razgovarati s bolesnikom i dobiti njegov verbalni odgovor, što će biti ne samo informacija o prohodnosti dišnog puta već i o stanju svijesti bolesnika. Obzirom kako se u velikom postotku radi o bolesnicima pod utjecajem droge ili alkohola, taj se podatak pri primarnoj procjeni ne bi smio smatrati razlogom poremećaja svijesti, već se primarno mora posumnjati na hipoksiju koju treba oslobađanjem dišnog puta i primjenom kisika korigirati. Istovremeno je potrebno slušati i definirati karakteristiku zvukova tijekom disanja poput stridora, hrkanja ili grgljanja što upućuje na ozljedu gornjih dišnih puteva npr. grkljana ili strano tijelo kao što su zubi ili dijelovi proteze koji su nasjeli na vokalne nabore. U bolesnika koji je pri svijesti zauzimanje sjedećeg položaja s protruzijom glave prema naprijed puno je ugodnije zbog drenaže krvi i sekreta kroz usta i nos prema van, umjesto da se isti slijevaju niz hipofarings uzrokojući kašljanje i eventualno aspiraciju. Ukoliko se radi o bolesniku bez svijesti ležeća ili polusjedeća pozicija se preporuča s naglaskom na kontrolu vratnje kralježnice uz minimalne pomake pri oslobađanju dišnog puta. Postupci koji se poduzimaju su: čiśćenje usne šupljine od jasno vidljivih potencijalnih uzrka obstrukcije uz pomoć sukcije ili Magill forcepsa, podizanje donje čeljusti u svrhu oslobađanja dišnog puta, ukoliko su oba postupka bezuspješna povlači se jezik prema naprijed (uz pomoć gaze ili stavljanjem šava na jezik što više prema dorzumu). Ukoliko se radi o obostranom prijelomu mandibule, jezik gubi prednju potporu pa se u tom slučaju dišni put oslobađa povlačenjem prednjeg dijela mandibule. Djelomična opstrukcija dišnog puta može nasta-

\section{INTRODUCTORY LECTURES}

I1 MAXILLO-FACIAL TRAUMA TREATMENT ACCORDING TO ETC/ ERC GUIDELINES (EUROPEAN TRAUMA COURSE / EUROPEAN RESUSCITATION COUNCIL)

Alen Protić

Department of Emergency Medicine, University Hospital Center Rijeka, School of Medicine, University of Rijeka

Lecture aim: the importance of securing the airway in maxillofacial trauma, the relation between facial trauma and neck vertebrate, the procedures with massive head and neck hemorrhage. Introduction: Violence is the leading cause of maxillofacial trauma even in the developed countries. Around $50 \%$ of violence victims have elevated alcohol concentration in their blood. In such cases most of the injuries are isolated injuries of facial bones like: zygotic bone, nasal bone, and mandible. More serious injuries of maxilla, ethmoid and other bones are characteristic for traffic accidents and falls with combined abdominal and thoracic injuries. Evaluation and procedure: it involves all the procedures done during first two hours before the team for maxillofacial injury comes and without managing the harder injuries before the team comes. Primary evaluation and resuscitation: primary evaluation predicts evaluation and treatment of life threatening injuries. During primary evaluation it is not necessary the precisely define facial injury. First team on the site should only worry about life threatening situations like airway obstruction and neck vertebrate control, breathing and ventilation, circulation and bleeding control, CNS dysfunction, and body exposure. Airway and neck vertebrate control: airway obstruction is the leading cause of death with maxillofacial trauma. The best way to check the airway is to talk to the patient and wait for his/hers verbal response. This way we gain information about patient's airway and his state of conscience. Since in large percentage of cases patients with such injuries are under influence of alcohol or drugs, the evaluation of conscience should not be influenced by the level of blood toxins, but we should assume that the patient is experiencing hypoxia that is ought to be treated by clearing the airway and administering oxygen. At the same time one should listen and define the sound characteristic during breathing like stridor, snoring or gargling which indicates the injury of the upper airway (larynx, foreign body obstructing the airway like teeth or dentures). Conscious patients are more comfortable in sitting position so that the blood and the nasal secretion can leak out and not in their throats causing aspiration. If the patient is unconscious, the horizontal position is the best choice with attention towards neck vertebrate during airway clearance. Procedures: cleaning the oral cavity from potential obstruction causes using suction or Magill forceps. Lower jaw should be elevated in order to free the airway. If both methods are unsuccessful, the tongue should be pulled out (using gauze or a stich). If the mandible is fractured on both sides, the tongue loses its support so the best was to clear the airway is to pull the mandible forward. Partial obstruction can happen if the mandible is fractured and the fractured part is moved backwards (bottom front teeth move in front of the upper teeth). Again the mandible should be moved forward in order to clear the airway. From simple aids made to maintain the airway circulation, oro-pharyngeal one is the one that is mostly used in these situations but it is not tolerated well in 
ti pri frakturi maksile s pomakom prema straga (klinički nalaz je prolaz donjih prednjih zubiju ispred gornjih) pa se povlačenjem maksile prema naprijed može oslobodti dišni put. Što se jednostavnih pomagala za opskrbu dišnog puta tiče upotrebljava se oro faringealni airway koji se u budnog bolesnika loše tolerira i lako se pomakne iz željene pozicije, nazo faringealni airway koji se bolje tolerira u budnijeg bolesnika i bolje ostaje fiksiran u željenoj poziciji ali postoji određna opasnost malpozicije pri frakturama baze lubanje. Oba airway-a nisu dostatna zaštita dišnog puta od aspiracije krvi i povraćanog sadržaja, te zahtjevaju stalnu sukciju kako se ne bi opstruirali. Bolja ventilacija i bolja zaštita od krvi koja se slijeva uslijed maksilofacijalne ozljede postiže se laringealnom maskom no i tu nije potpuna zaštita dišnog puta pogotovo ako se radi o aktivnom povraćanju, a uz to budan bolesnik bez dobre analgosedacije neće dobro tolerirati laringealnu masku. Laringealna maska je stoga izbor u besvjesnog bolesnika te ukoliko se ne vlada tehnikom endotrahealne intubacije. Endotrahealna intubacija zlatni je standard osiguravanja dišnog puta čime se postiže potpuna kontrola ventilacije uz osiguranje dišnog puta od krvi i povraćanog sadržaja. Nedostaci su: potreba za analgosedacijom te zahtjevnija edukacija same vještine. U slučaju neuspjeha svih pokušaja oslobađanja dišnog puta jednostavnim pomagalima uključujući i ET intubaciju, potrebno je pristupiti kirurškom otvaranju dišnog puta. Konikotomija je tehnika kojom se prereže kriko-tiroidna membrana te se kroz nastali otvor postavlja kanila predvidena za tu namjenu (postoji set za hitnu konikotomiju). Kao manje invazivna alternativa je konikotomija iglom koja omogućava oksigenaciju ali ne i ventilaciju. Traheotomija spada u semi-elektivni postupak i nije predmet hitnog zbrinjavanja dišnog puta osim u slučaju frakture grkljanja ili u djece mlađe od 12 godina gdje trebalo bi pokušati izbjegavati konikotomiju zbog kasnijih teških komplikacja. Disanje ventilacija: Ciljevi su: potpora ako je neadekvatno disanje, odmah riješiti po život opasna stanja vezana za prsište. Prije postavljanja ovratnika radi stabilizacije vratne kralježnice uz pomoć asistenta koji manualno imobilizira vrat potrebno je pregledati vrat te utvrditi postojanje ili ne postojanje 5 znakova na vratu: rane, proširene vratne vene, pozicija traheje, subkutani emfizem, laringealne krepitacije. Upravo navedeni znakovi na vratu mogu pomoći pri dijagnosticiranju nekih po život ugrožavajućih stanja kao što su: fraktura grkljana (laringealne krepitacije, subkutani emfizem), tenzijski pneumotoraks (proširene vratne vene, devijacija traheje, subkutani emfizem), tamponada srca (proširene vratne vene), perforacija jednjaka (subkutani emfizem). Rane na vratu koje sežu dublje od platizme nije uputno eksplorirati, jer i ozljeda unutrašnje jugularne vene može sama sebe tamponirati, stoga je nužno da se takve rane obrade u operacijskim dvoranama s odgovarajućim instrumentima i osobljem. Prsište je potrebno sistematski i strukturirano pregledati u smislu: inspekcije (frekvencija disanja, napor pri disanju, simetričnost, rane \& oznake/tragovi), palpacija u srednjoj aksilarnoj liniiji i prednje strane (krepitacije kostiju, subkutani emfizem), - perkusija u srednjoj aksilarnoj liniji, iznad i ispod bradavica (hipo ili hipersonaran zvuk, usporedba obe strane), - auskultacija u srednjoj aksilarnoj liniji, iznad i ispod bradavica, - provjera leda! Pet po život ugrožavajućih ozljeda prsišta su: tenzijski pneumotoraks, otvorena rana prsišta, masivni hematotoraks. lebdeće prsište, tamponada srca. Ukoliko se radi o životno ugroženom bolesniku neovisno dali se radi o izolranim ili udruženim ozljedama kojega je potrebno ET intubirati i ventilirati nužno je voditi računa o: poziciji/dužini endotrahealnog tubusa, udisajnom volumenu, frekvenciji, vršnom udisajnom tlaku te o FiO2, etCO2, SpO2. Cirkulacija i kontrola krvarenja: Glavnina problema vezano za maksilofacijalne ozljede upravo je A i C, iako treba naglasiti kako je potrebno biti oprezan pri procjeni uzroka hemoragičnog šoka koji bez obzira na naizgled dramatično krvarenje iz područja lica najvjerovarnije ima i svoju pozadinu u ozljedi organa abdomna, zdjelice ili toraksa. Iako je tkivo glave i vrata izrazito dobro perfundirano, osim teške ozljede viscerokraniuma, ozljede većih krvnih žila vrata ili skalpa u djece, ostale maksilofacijalne ozljede ne bi trebale biti uzrok većeg gubitka krvi. Kontrola krvarenja u ustima i orofarinksu važna je ne samo zbog gubitka krvi već i zbog održavanja dišnog puta, što je dodatno otežano kod potrebe za imobilizacijom vratne kralježnice kada je nužna pozicija ravno na ledima prilikom čega se krv sljeva upravo prema hipofaringsu i time ugrožava dišni put. Veći dio krvarenja se može kontrolirati pritiskom, pri ozljedi jezika su zbog njegove izrazito dobre prokrvljenosti potrebni duboki šavovi. Lokalni anestetik s adrenalinom može također pomoći u smanjivanju krvarenja. Krvarenje iz stražnjeg dijela nosa najčešce nastaje uslijed prijeloma maksile, a može biti udruženo is prijelomom baz lubanje prednjom se tamponadom vrlo često ne može zaustaviti. U navedenom slučaju važno je pogotovo u bolesnika s poremećajem svijesti osigurati dišni put ET intubacijom, međutim zbog potencijalnog većeg gubitka krvi nužno je odmah po osiguravnju dišnog puta pristupiti zaustavljanju krvarenja. Podizanje bolesnika u anti-trendelenbug poziciju u smslu podizanja glave može smanjiti venski tlak i na taj način se smanji krvarenje. Postavljanje dva Foley (urinarnog) kaketera (manje dimenzije) u obje nosice, prolaskom do iza mekog nepca, napuhivanjem cuffa te povlačenjem prema naprijed čineći tamponadu stražnjeg dijela nosa, krvarenje se može zaustaviti, nakon čega će biti potrebno u većem broju slučajeva učiniti i prednju tamponadu. Ukoliko se ne radi o udruženoj ozljedi mozga ciljani sistolički tlak bi trebalo održavati na $80 \mathrm{mmHg}$. Materijal iz priručnika ETC / ERC; Chapter 13: Maxillofacial trauma conscious patients. Naso-pharyngeal airway is better tolerated by conscious patients and it stays fixated better with the exception of cranial base fracture where there is a certain danger of aid malposition. Both airway aids are not good enough protection against blood and vomit aspiration so a constant suction should be administered. Better ventilation and better protection from aspiration is done by using the laryngeal mask but this device does not provide protection against active vomiting. Patients who are sedated and anesthetized react better to laryngeal mask. Laryngeal mask is a method of choice unless a therapist mastered the method of endotracheal intubation. Endotracheal intubation is a golden standard for securing the airway and ventilation from blood and vomit. The disadvantages are: the need for sedation which requires special skills. In case all the pre mentioned methods fail, one needs to utilize the surgical approach to airway clearance. Conicotomy is a technique used to sever the crico-thyroid membrane and to insert the cannule made for that specific purpose (there is a set for emergency conicotomy). As a less invasive alternative there is a conicotomy technique using a needle that allows oxygenation but not ventilation. Tracheotomy is a semi-elective procedure and does not present an emergency procedure for airway ventilation except in a case of fractured larynx or in kids less than 12 years where conicotomy should be avoided because of latter complications. Breathing and ventilation: the goal is to support the inadequate breathing and to resolve the life threatening thoracic condition. Before placing the collar to support the neck it is important to check the neck for 5 signs: wounds, dilated veins, position of the trachea, subcutaneous emphysema and laryngeal crepitation. The pre mentioned signs can help to diagnose several life threatening conditions: fractured larynx (laryngeal crepitation, subcutaneous emphysema), tensional pneumothorax (varicose veins, tracheal deviation, and subcutaneous emphysema), heart tamponade, esophagus perforation (subcutaneous emphysema). Neck wounds that go deeper than platysma should not be explored because the jugular can tamponade itself and these types of injuries should be left to be treated by surgical team. Thorax should be thoroughly inspected in the way: inspection (breathing frequency, breathing strain, symmetry, wounds and marks), palpation in the mid axial line (bone crepitation, subcutaneous emphysema), percussion in mid axial line, above and below nipples (hypo or hyper sonar sound), auscultation in the mid axial line, above and below nipples and back check. Five life threatening thoracic injuries are: tensional pneumothorax, open wound, massive hemo-thorax, heart tamponade, and floating chest. If the patient is in life threatening condition no matter if the situation consists of isolated or compound injuries, the patient needs endotracheal intubation and the focus should be in the length of the endotracheal tube, breathing volume, frequency, top breathing pressure, FiO2, etCO2, SpO2. Circulation and bleeding control: most of the problems associated with maxillofacial injuries are airway and circulation problems. It should be emphasized that bleeding from face is not as dramatic since it is probably accompanied with more serious injuries in thorax, abdomen or pelvis. Even though the head and neck tissue is heavily vascularized, beside serious viscero-cranial injury, the larger blood vessels injury or the scalp in children, there should not be any larger blood loss with other maxillofacial injuries. Bleeding control in mouth and oropharynx is important not only because of the blood loss but because of the airway circulation which is hardened when neck vertebrate is immobilized when the patient is lying down thus forcing the blood to hypopharynx. Most of the bleeding can be controlled by exerting pressure. If the tongue is injured, it requires deep stiches since it is heavily vascularized. Local anesthesia with adrenaline can also slow down bleeding. Bleeding from the back of the nose is associated with maxilla fracture but it can also be joined with cranial base fracture. Tamponade often cannot stop such bleeding. In this case it is necessary to secure the airway with endotracheal intubation and immediately take care of the bleeding. Elevating the patient to anti-trendelenburg position can lower the venous pressure and lower the bleeding. By placing two Foleys (urinary) catheter in both nostrils, going behind the soft palate and blowing up the cuff and pulling it forward we create tamponade and stop the bleeding. In most cases this scenario requires a front tamoponade as well. In case we are not dealing with joined brain injury, the systolic pressure should be around $80 \mathrm{mmHg}$. Material from the manual ETC IERC; Chapter 13: Maxillofacial trauma 
I2 TRAUME BAZE LUBANJE - TIMSKI PRISTUP U LIJEČENJU Goran Bajek

Klinika za neurokirurgiju, KBC Rijeka, Medicinski fakultet, Sveučilište u Rijeci

I3 MOGUĆNOSTI USAGLAŠAVANJA U NOMENKLATURI KRANIOFACIJALNIH PRIJELOMA

Naranđa Aljinović Ratković

Klinika za kirurgiju lica, čeljusti i usta, KB Dubrava, Medicinski fakultet, Sveučilište u Zagrebu

Nomenklatura (nazillja) pojedinih prijeloma srednjega lica u kliničkoj primjeni gotovo su nepromijenjena već više od sto godina unatoč brojnim novim spoznajama kroz sofisticiranu dijagnostiku (CT, MSCT) i brojnim publiciranim potpodjelama,. U pravilu se koriste pojmovi: prijelom maksile prema Le Fortu, prijelom zigomatične kosti i prijelom orbite koji se najčešć koristi kao sinonim za blow-out tip prijeloma. Kompleksniji prijelomi i oni koji se u ovu jednostavnu podjelu ne mogu uvrstiti nazivaju se različitim nazivima. Siromašnost ove nomenklature i neusaglašenost u izboru naziva za prijelome izvan opsega navedenih naziva rezultirala je da često isti tipovi prijeloma bivaju nazivani različitim nazivima. Iz toga proizlazi nemogućnost utvrdivanja stvarne dijagnoze na osnovi pisanih nalaza već potvrdu opsega možemo utvrditi tek pregledom CT snimaka, ako su dostupni. Kao dokaz navedenih tvrdnji analizirano je 300 nasumično izabranih bolesnika s MKB10 dijagnozama S02.3 i S02.4 od ukupno 564 bolesnika koji su pod tim dijagnozama liječeni u razdoblju od 01.01.2009. do 31.12.2012. Uspoređene su dijagnoze otpusnih pisama i operacijskih lista s opisima operacija, opisima radioloških nalaza i CT snimkama. Najveće razlike utvrdene su za unilateralni prijelom tipa Le Fort III s kontralateralnim prijelomom tipa Le Fort II, koji 40\% liječnika naziva Le Fort II + zigomatični prijelom, te za prijelome orbite pod kojim pojmom se mogu naći blow-out prijelomi, izolirani prijelomi raznih lokalizacija (krov, medijalni zid), nazoorbitalni prijelomi i veliki broj prijeloma zigomatične kosti (naročito kada je izrazitije involvirano dno orbite). Također je uočeno da se prijelome tipa Le Fort II ili III po tipu Wasmund II naziva Le Fort + NOE. Dodatni problem u nazivlju stvara istovremena uključenost neurokranija koja uopće nije definirana. U radu se predlaže simplificirana modifikacija raznih kompliciranih potpodjela kojom bi se uvelo jedinstveno pisano nazivlje i olakšala komunikacija među specijalistima, procjena ozljede i procjena rezultata liječenja kao i sudsko-medicinska procjena.

\section{I4 MOGUĆNOSTI REKONSTRUKCIJE OZLJEDA UZROKOVANIH} TRAUMOM

Vedran Uglešić

Klinika za kirurgiju lica, čeljusti i usta, KB Dubrava, Stomatološki fakultet, Sveučilište u Zagrebu

Mandibula je važna za govor, žvakanje, gutanje, potporu disanja i glavni je estetski aspekt lica. Cilj naših rekonstruktivnih zahvata je definirati preoperativne funkcije i estetiku lica prije traume kako bi mogli rekonstruirati defect na odgovarajući način te omogućiti pacijentu normalan obiteljski i društveni život. U ovom prikazu slučaja navedene su indikacije i kontraindikacije za mikrovaskularnu rekonstrukciju i ostale kirurške zahvate. Isto tako ćemo navesti karakteristike idealnog mikrovaskularnog režnja te prodiskutirati o kompozitnom režnju podlaktice, DCIA, lopatičnim i fibularnim režnjom te ćemo ocijeniti sve režnjeve ovisno o njihovim karakteristikama. Fibularni režanj predstavlja režanj izbora kod rekonstrukcije mandibule. Nakon fibularnog režnja slijedi DCIA, lopatični i režanj podlaktice.

\section{5 ŠTO UČINITI SA ZUBOM U PRIJELOMNOJ PUKOTINI DONJE} ČELJUSTI?

Darko Macan, Davor Brajdić

Klinika za kirurgiju lica, čeljusti i usta, KB Dubrava, Stomatološki fakultet, Sveučilišste u Zagrebu

Prijelomna pukotina u kojoj je zub komunicira preko parodontne pukotine s usnom šupljinom što predstavlja ulazna vrata infekciji. Ošstećenje apeksnih krvnih žila može prouzročiti gubitak vaskularizacije pulpe i posljedičnu nekrozu pa takav zub postaje izvor infekcije. Danas su još uvijek različita stanovišta i postupci autora prema zubu u prijelomnoj pukotini. Većina autora smatra da više ne vrijedi pravilo da svaki zub u pukotini treba odstraniti te zagovaraju selektivni stav i individualni pristup. Kriteriji za odluku su: mobilnost zuba u pukotini, pridruženi prijelom korijena, periapeksne patološke promjene te uloga zuba u stabilizaciji i fiksaciji ulomaka. Ipak, i dalje su kontroverzni stavovi o ulozi ranije repozicije i dislokacije ulomaka na reinervaciju, prognozi zuba ako prijelomna pukotina zahvaća apeks, prognozi impaktiranih umnjaka u prijelomnoj pukotini, utjeca-

\section{I2 CRANIAL BASE TRAUMA - TEAM APPROACH TO TRETMENT} Goran Bajek

Department of Neurosurgery, University Hospital Center Rijeka, School of Medicine, University of Rijeka

13 THE POSSIBILITIES OF COMPLIANCE IN CRANIOFACIAL FRACTURE NOMENCLATURE

Naranđa Aljinović Ratković

Department of Maxillofacial and Oral Surgery, University Hospital Dubrava, School of Medicine, University of Zagreb

Nomenclature of certain mid-face fractures in clinical use has not changed for more than 100 years despite the new discoveries using the sophisticated diagnostics (CT, MSCT) and numerous subdivisions. In general we use: maxillary fracture according to Le Fort, zygoma fracture and orbital fracture, mostly used diagnosis when talking about blow-out fractures. More complex fractures and the ones that cannot be classified under the pre mentioned fractures are called with various names. The poor nomenclature and discrepancies in the names beyond the scope of pre mentioned fractures often results in a case where the same type of fracture is often has several different names. This creates a situation where it is often impossible to assess the proper diagnosis based solely on the written report and clinician can only determine the scope of fracture using sophisticated equipment like CT scans if available. In order to support the claimed facts, we analyzed 300 randomly chosen patients with MKB10 diagnosis S02.3 and S02.4 out of 564 patients with the same diagnosis treated at our Department during the period from January 1st, 2009 till December 31st 2012. We compared the release forms and operational lists with operation description, $\mathrm{x}$-rays and CT scans. The largest difference was determined for the unilateral Le Fort III fracture with contralateral Le Fort II fracture that is in $40 \%$ of the cases called Le Fort II fracture combined with zygomatic fracture. Orbital fractures were combined with blow-out fractures and isolated fractures with different localization (orbital roof, medial wall) as well as nasal and orbital fractures with large number of zygomatic fractures (especially combined with the orbital floor fracture). It was also noticed that Wasmund II type of Le Fort II and III fractures are called Le Fort + NOE. Additional problem presents the involvement of the neurocranium in the description of the fracture that itself is not defined at all. This paper suggests simplified modification of various complicated subdivisions that would unify the written reports and simplified the communication between specialists, injury evaluation and outcome of the treatment as well as the court medical expert report.

\section{I4 RECONSTRUCTION POSSIBILITIES OF POST-TRAUMATIC DEFECTS \\ Vedran Uglešić \\ Department of Maxillofacial and Oral Surgery, University Hospital Dubrava, School of Dental Medicine, University of Zagreb}

The mandible assists in verbalization, oral competence, mastication, deglutination, airway support, and is a major aesthetic highlight of the face. Our reconstructive goal is redefine the preoperative functions and facial aesthetics and return patient to a normal family and social life. In presentation indications and contraindications for microvascular reconstruction and surgical technique will be discussed. Characteristics of ideal microvascular flap will be outlined and composite forearm flap, DCIA, scapula and fibula flap wi$\| l$ be scored according these characteristics. The fibula flap seems to be the first choice for the mandible reconstruction followed by DCIA, scapula and forearm flap.

\section{WHAT TO DO WITH THE TOOTH IN A MANDIBULAR FRACTURE LINE \\ Darko Macan, Davor Brajdić \\ Department of Maxillofacial and Oral Surgery, University Hospital Dubrava, School of Dental Medicine, University of Zagreb}

Mandibular fracture line containing a tooth presents an infection hazard since it acts as a communication pathway between oral cavity and the periodontal fibers. If the blood vessels surrounding the root apex become damaged, such tooth will lose its pulpal blood supply and the pulp will become necrotic thus becoming a source of infection. Even today authors have diverging opinions regarding the affected tooth. Majority of authors consider that every tooth in such condition should not be removed, but they also support selective and individual approach. Decision criteria are: tooth mobility, root fracture, periapical pathologies and the tooth's role in stabilization and fixation of the fractured mandible. Nevertheless, the controversies remain around the role of early reposition and fragment dislocation on reinervation, tooth prognosis if the fracture line reached the 
ju načina liječenja na zub u prijelomnoj pukotini, prognozi zubnih zametaka u prijelomnoj pukotini u djece te što prije učiniti - alveotomiju ili osteosintezu?

I6 MAKSILOFACIJALNA TRAUMATOLOGIJA U KBC OSIJEK: TRINAEST- GODIŠNJI PREGLED

Dinko Leovićć, Vedran Zubčić, Bruno Popić, Dražen Dražić, Vlatko Kopić, Stjepan Siber, Marko Matijević, Kristijan Dinjar, Ivan Mumlek, Branko Janković

KBC Osijek, Odjel za maksilofacijalnu kirurgiju, 'Medicinski fakultet, Sveučilište u Osijeku

Cilj ovoga rada je prezentirati trinaest-godišnji pregled liječenja fraktura kosti lica u našoj ustanovi. Pregled obuhvaća period od 2000. do kraja 2012. godine. Ukupno je liječeno 771 bolesnika s frakturama kostiju lica. Najčešće frakture bile su frakture zigomatič ne kosti ; $329(42,7 \%)$ i mandibule; 281 (36,5\%). Fraktura maksila bilo je 65 (8,5\%), orbite 28 (3,6\%) i višeetažnih $90(11,7 \%)$. Najveći broj pacijenta stradao je u prometnim nesrećama; 33,6\% i zbog nasilja; 26,8\%. Distribucija bolesnika bila je podjednaka je u svim godišnjim dobima. Nešto veći broj bolesnika stradao je tijekom vikenda; $53 \%$ u odnosu na radne dane; $47 \%$. Svi tipovi fraktura se danas u više od $70 \%$ liječe otvorenom osteosintezom, za razliku od perioda 2000.-2005. kada je oko 70\% bolesnika liječeno konzervativno.

\section{MAKSILOFACIJALNA TRAUMA U DVADESET-TROGODIŠNJEM RAZDOBLJU KBC RIJEKA \\ Mirna Juretić}

Klinika za maksilofacijalnu i oralnu kirurgiju, KBC Rijeka, Medicinski fakultet, Sveučilište u Rijeci

Na učestalost i vrstu maksilofacijalnih ozljeda utječu brojni čimbenici; demografski, oni koji su povezani s načinom života i standardom društva. Ti se čimbenici vremenom mijenjaju uzrokujući uočljive promjene kako u incidenciji, vrsti maksilofacijalnih ozljeda, mehanizmu njihovog nastanka, tako i u načinima kirurškog liječenja. O incidenciji i vrstama maksilofacijalnih ozljeda postoje brojne epidemiološke studije iz različitih zemalja svijeta. Cilj naše retrospektivne studije je prikazati maksilofacijalne ozljede tijekom 23godišnjeg razdoblja. Obradili smo 1868 bolesnika s 2532 maksilofacijalne ozljede u razdoblju od 1990. do 2012. godine. Istraživanje je obuhvatilo: dob, spol, mehanizme ozljede s osvrtom na učestalost alkoholiziranih pacijenata prilikom stradavanja, udružene ozljede drugih djelova tijela, tip i anatomsku lokalizaciju maksilofacijalne ozljede te načine kirurškog liječenja. Podaci su posebno komparirani prema dva razdoblja: prvo razdoblje u vremenu od 1990. do 2001. godine, a drugo razdoblje od 2002. do 2012. godine. Prosječna dob ispitanika bila je 36 godina s najviše ozlijeđenih unutar skupine od 20 do 29 godina. Gledano prema spolu najbrojniji ( $81 \%$ ) su bili muškarci, a odnos spolova 4:1 u korist muškog spola. Najčešći uzrok ozljeda bile su prometne nesreće (43\%), nakon njih nasilja raznih vrsta (32\%) i nesretni padovi (22\%). U drugom vremenskom razdoblju (2002.-2012.) značajan je porast nasilja i padova u incidenciji maksilofacijalnih ozljeda, tako da su te dvije kategorije postale učestalije od prometnih nesreća. Najčeśće ozlijeđena kosti bila je mandibula (46\%), a od pridruženih tjelesnih ozljeda najčešće su bile kraniocerebralne ozljede (39\%). Otvorena repozicija kosti i osteosinteza ulomaka bila je najčešća metoda kirurškog liječenja. Rezultati istraživanja su pokazali značajne promjene čimbenika odgovornih za nastanak i vrstu maksilofacijalne ozljede, kao i način kirurškog liječenja u dva promatrana vremenska razdoblja, šso se može objasniti demografskim i socijalnim promjenama u društvu.

\section{I8 DESET NAŠIH KONGRESA - RETROSPEKTIVNA ANALIZA Njegoslav Bušić \\ Odjel za maksilofacijalnu kirurgiju, KBC Split}

Uvod: Izvršsena je retrospektivna analiza svih deset dosadašnjih kongresa Hrvatskog društva za maksilofacijalnu, plastičnu i rekonstrukcijsku kirurgiju glave i vrata, u referentnom razdoblju od 1999. do 2013. godine. Cilj rada bio je pokušati ustvrditi trendove koji bi mogli imati upliva na budućnost struke. Materijal $i$ metode: Izvor podataka bile su konačne obavijesti sa stručnim programima svih dosadašnjih kongresa Društva. Učinjena je kvantitativna analiza dobivenih podataka, bez vrednovanja "stručne težine" prezentiranih radova i bez subjektivnih komentara istraživača. Rezultati: Prvi Kongres je održan u Zagrebu (1999), drugi u Osijeku (2000), treći u Lovranu (2001), četvrti u Splitu (2002), peti u Zadru (2003), šesti u Zagrebu (2004), sedmi u Rijeci (2006), osmi u Osijeku (2008), deveti u Splitu (2011), te deseti u Malinskoj (2013). Ukupan broj prezentiranih radova bio je 548. Najveći broj radova na svakom pojedinačnom kongresu i u ukupnom zbroju dolazio je od autora iz KB Dubrava (ukupno 188 radova ili 33\%). Na kongresima su sudjelovali i autori drugih specijalnosti, najviše oralni kirurzi, s ukupno 202 rada ili $37 \%$. Inozemni autori prezentirali su ukupno $64 \mathrm{rada}(12 \%)$. Na posljednjih osam kongresa root apex, the prognosis of tooth buds in the fracture line and what to do first - alveotomy or osteosythesis?

I6 MAXILLOFACIAL TRAUMATOLOGY IN UNIVERSITY HOSPITAL OSIJEK: A THIRTEEN YEARS REVIEW

Dinko Leović ${ }^{1}$, Vedran Zubčić, Bruno Popić, Dražen Dražić, Vlatko Kopić, Stjepan Siber, Marko Matijević, Kristijan Dinjar, Ivan Mumlek, Branko Janković

University Hospital Center Osijek, Department of Maxillofacial Surgery,

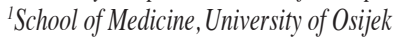

The aim of this study is to present the thirteen years review of maxillofacial trauma in our Institution. The review includes the period from 2000 until the end of 2012. The overall number of patients with facial fractures was 771 . The most prominent sites of fractures were zygomatic bone; $329(42.7 \%)$ and mandible; $281(36.5 \%)$. There were $65(8.5 \%)$ maxillary fractures, $28(3.6 \%)$ fractures of the orbita and $90(11.7 \%)$ multilevel fractures. The most important etiological factors were traffic accidents; $33.6 \%$ and violence; $26.8 \%$. Interseasonal distribution of the patients was equal. More patients have been admitted during weekends: $53 \%$, comparing to other days in the week; $47 \%$. Nowadays, more than $70 \%$ of all types of fractures are treated by surgical osteosynthesis, comparing to the period form 2000 to 2005 when approximately $70 \%$ of fractures had been treated conservatively.

\section{MAXILLOFACIAL INJURIES DURING THE 23 YEARS PERIOD} UNIVERSITY HOSPITAL CENTER RIJEKA

Mirna Juretić

Department of Maxillofacial and Oral Surgery, University Hospital Center Rijeka, School of Medicine, University of Rijeka

Epidemiological parameters of maxillofacial injuries depend on numerous factors that influence the way of living: demographic parameters, social standard and life conditions. This factors change throughout the years causing the inevitable change in incidence, mechanism, and type of maxillofacial injury, as well as the surgical treatment of injuries. Numerous epidemiological studies indicated characteristics in the incidence of maxillofacial injuries in various countries of the world. The objective of this retrospective study was to find out the incidence and pattern of maxillofacial injuries and to determine the changes of the mentioned throughout the 23-year period. The total of 1868 patients with 2532 maxillofacial injuries treated at our Department was evaluated from the period since 1990 to 2012. Data referred to age, gender, injury mechanism, concomitant systemic injuries, drinking habits of the patients, anatomical site and type of maxillofacial injury and surgical treatment. Data were also studied separately in two decades; the first period since 1990 to 2001 and the second since 2002 to 2012. The average age of patient was 36 with the peak occurrence in the 20-29 age groups. In terms of gender, the highest percentage of $81 \%$ was noticed in male patients with male:female proportion $4: 1$. The most often cause of the incidence of injuries were traffic accidents (43\%), followed by violence $(32 \%)$ and accident falls (22\%). Surprisingly, in the next decade the shift occurred with the violence assault as the most often cause followed by accident falls and traffic accidents. The scale of the most frequently fractured bone was led by the mandible (46\%), while craniocerebral injuries (39\%) were the most common concomitant lesions. Open reduction and osteosynthesis is the most frequent sort of treatment of all fractures. The results show many changes in factors related to injuries, including injury mechanism, types of fracture and surgical treatment during two period-decades, which can be explained by certain change in demographic and social circumstances.

\section{I8 OUR TEN CONGRESSES - A RETROSPECTIVE ANALYSIS Njegoslav Bušić \\ Department of Maxillofacial Surgery, University Hospital Center Split}

Introduction: Data were obtained through analysis of the ten previous Congresses of the Croatian Society for Maxillofacial, Plastic and Reconstructive Head and Neck Surgery, in the reference period from 1999 to 2013 year. The aim of the study was to find out the trends that could have an influence on the future of this profession. Materials and Methods: The data source was the final notices with programs of all previous congresses. A quantitative analysis of the data was performed, without evaluating the "expert difficulty" of the papers and without subjective comments of researcher. Results: The first Congress was held in Zagreb (1999), the second in Osijek (2000), the third in Lovran (2001), the fourth in Split (2002), fifth in Zadar (2003), sixth in Zagreb (2004), seventh in Rijeka (2006), eighth in Osijek (2008), ninth in Split (2011), and tenth in Malinska (2013). The total number of the papers was 548 . The largest number of papers on each Congress in the total sum came from the authors from University Hospital Dubrava (a total of 188 papers, or $33 \%$ ). Authors of other specialties, mostly oral surgeons, participated in our Congresses with a total of 202 or $37 \%$. Foreign authors have presented a total 
članovi Društva tajnim glasovanjem birali su specijalizanta godine. Specijalizantski radovi imali su udjel od 70 radova (13\%). Udjel postera u ukupnom broju radova bio je 3\%. Ukupno je bilo 199 prvih autora i 304 koautora. Najplodonosniji prvi autori bili su Bušić Nj., Aljinović-Ratković N. i Virag M., a koautori Virag M., Macan D. i Uglešić V. Najveći broj radova na pojedinom kongresu (ukupno 7) imao je Virag M. Kao prvi autori na svih deset kongresa sudjelovala su samo četiri člana Društva (Aljinović-Ratković N., Bušić Nj., Knežević P. i Leović D). Kao koautor na svih deset kongresa sudjelovao je samo Virag M. U okviru stručnih dijelova kongresa bili su organizirani i okrugli stolovi. Osobito zanimanje pobudili su okrugli stolovi na temu blefaroplastike, face-liftinga, tretmana loših rezultata i orofacijalne boli. Po tematici najbrojniji su bili radovi vezani uz onkokirurgiju (118), te rekonstruktivnu kirurgiju (100), a slijede oralnokirurške teme, traumatologija, malformacije, deformiteti, estetska kirurgija i upale. Preostali radovi, svrstani u kategoriju "ostali", dio su širokog dijapazona kazuistike koja se nešto rjeđe sreće u maksilofacijalnoj praksi. Zakljucci: Ovom retrospektivnom analizom nisu uočeni trendovi koji bi utjecali na budućnost struke. Ipak, istraživanje je otvorilo pitanje stručnog naslijeđa nakon deset održanih kongresa i ukazalo na potrebu objarljivanja zbornika kongresnih prezentacija, kao trajne baštine rada Društva. Preporuka je retrospektivnu analizu proširiti u longitudinalno istraživanje u cilju unaprijeđenja koncepcije razvoja Društva i spriječavanja stagnacije struke u cjelini.

\section{PREDAVANJA}

\section{TRAUME ČELIUSTI KOD ŽRTAVA DOMOVINSKOG RATA}

Mato Sušić1, Irina Filipović Zore ${ }^{1}$, Juraj Brozović² ${ }^{2}$ Davor Strinović ${ }^{3}$, Hrvoje Brkić4, Dragana Gabrić Pandurićc

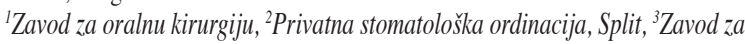
sudsku medicinu i kriminalistiku, Medicinski fakultet, Sveučilište u Zagrebu,

${ }^{4}$ Zavod za dentalnu antropologiju, Katedra za forenzičku stomatologiju, ${ }^{1,4}$ Stomatološki fakultet, Sveučilište u Zagrebu, Klinika za stomatologiju, KBC Zagreb

Svrha ovoga istraživanja bila je dokazati i analizirati vrstu ozljeda čeljusti na ekshumiranim tijelima iz masovnih i individualnih grobnica lociranih na okupiranim područjima tijekom Domovinskog rata u Hrvatskoj od 1991. do 1995. Korišstena je postmortalna dokumentacija orofacijalne regije 1068 žrtava ekshumiranih iz masovnih grobnica u Hrvatskoj. Prisutnost traumatizma je analizirana za čitav uzorak, kao i individualno po grobnicama. Analiza frekvencije trauma je učinjena pojedinačno. Napravljena je deskriptivna statistička obrada gdje je vrijednost $\mathrm{p}<0.05$ smatrana statistički značajnom. Od 1068 ekshumiranih tijela, $332(31,1 \%)$ su imala prijelome srednjeg i donjeg lica. Prijelomi donjeg lica su bili učestaliiji (28,1\%). Statistička značajnost nađena je u relaciji starosti jedinke i frekvenciji ozljede. 34,6\% prijeloma nađeno je u skupini ispod 30 godina, $34,2 \%$ u skupini 30-60 godina te 21,3\% prijeloma u skupini iznad 60 godina starosti. Manje ozljeda nađeno je kod žena, bez obzira na postojanje osteoporotičnih promjena. Rezultati ovoga istraživanja ukazuju da je populacija mlađe i srednje životne dobi bila više mučena. Prijelomi čeljusti sugeriraju ante-mortalno mučenje. Kod žena, za razliku od toga, prijelomi su čeśce bili uzrokovani padom u grobnicu ili udarcem tijela o tijelo.

02 TRZAJNE OZLJEDE TEMPOROMANDIBULARNOG ZGLOBA Irina Filipović Zore ${ }^{1}$, Aljoša Matejčićc ${ }^{2}$ Z Zvonimir Zore ${ }^{3}$, Asja Ćelebić ${ }^{4}$

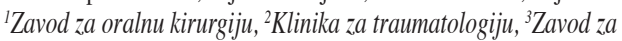
onkoplastičnu kirurgiju, ${ }^{4}$ Zavod za mobilnu protetiku, ${ }^{1,2,4}$ Stomatološki fakultet, Sveučilište u Zagrebu, ${ }^{1,4} \mathrm{Klinika}$ za stomatologiju, KBC Zagreb, ${ }^{2,3} \mathrm{KBC}$, ,Sestre Milosrdnice"

Trzajna ozljeda (whiplash) definira se kao ozljeda koja nastaje kao posljedica naglog trzaja glavom naprijed-nazad. Ozljeda se uglavnom manifestira u gornjim dijelovima vrata, poglavito mekim tkivima, ali od trzaja nije pošteđen ni temporomandibularni zglob (TMZ). Takove ozljede najčešće su posljedice prometnog traumatizma kao akceleracijsko-deceleracijski incident, ali takve ozljede mogu nastati i kod pada na ledu ili kore od banane, te pri drugim sportskim ozljedama. Osnovna promjena koja se dogada u vratnoj kralježnici jest iščašenje kralježaka uz posljedično istegnuće mekih tkiva, mišića, živaca i krvnih žla. Kako je TMZ funkcionalni nastavak vratne kralježnice u zglobu dolazi do unutarnje poremećenosti. U hiperekstenziji se naglo i široko otvaraju usta, te se događa hipertranslacija kondila zajedno sa zglobnim diskom i posljedičnim oštećenjem retrodiskalnog tkiva. U deceleracijskoj pak fazi, odnosno hiperfeksiji, naglo se zatvaraju usta, kondili se kreću gore i natrag u glenoidnu udubinu, a disk ostaje u prijašnjoj anteriornoj poziciji. U radu se prikazuje povezanost wiplash ozljeda s promjenama u TMZ -u. U radu se prikazuje 15 bolesnika koje je opći kirurg - traumatolog nakon dijagnosticiranog of 64 studies (12\%). At the last eight Congresses, members of the Society elected a resident of a year. Resident's works had a share of 70 papers (13\%). Total share of posters in the number of papers was 3\%. Overall there were 199 lead authors and 304 co-authors. Most fruitful first authors were Bušić Nj., Aljinović-Ratković N. and Virag M., and coauthors Virag M., Macan D. and Uglešic V. Virag M. had the largest number of papers in a single Congress (7 total). Only four members of the Society (Aljinović-Ratković N., Bušić Nj., Kneževic P. and Leović D) participated as the first authors on all ten conferences. Virag M. was the only participant who attended as a co-author on all ten conferences. Roundtables were organized within the professional part of the congress. Particular interests at the roundtables were on the topic of blepharoplasty, face-lifting, treatment of poor results and orofacial pain. By topic, most numerous were papers related to oncosurgery (118), and reconstructive surgery (100), followed by oral surgical threads, trauma, malformations, deformities, cosmetic surgery and inflammations. The remaining papers, classified as "the other", were part of the wide range of casuistry that is somewhat rarely seen in maxillofacial practice. Conclusions: This retrospective analysis did not reveal trends that could have influence on the future of the profession. However, research opened a question of professional heritage after ten held congresses and indicated the need for publishing Proceedings/Book of Abstracts, as a permanent heritage of the Society. The recommendation is to expand the retrospective analysis in the longitudinal study in order to improve the concept of development of the Society and to prevent stagnation of the profession.

\section{ORAL PRESENTATIONS}

\section{JAW TRAUMA IN CIVIL WAR VICTIMS}

Mato Sušić ${ }^{1}$, Irina Filipović Zore ${ }^{1}$, Juraj Brozović ${ }^{2}$, Davor Strinović̂ ${ }^{3}$, Hrvoje Brkić4, Dragana Gabrić Pandurićl

${ }^{1}$ Department for Oral Surgery, ${ }^{2}$ Private dental office, Split, ${ }^{3}$ Department of

Forensic Medicine, School of Medicine, University of Zagreb, ${ }^{4}$ Department of Forensic Dentistry, ${ }^{1,4}$ School of Dental Medicine, University of Zagreb, Department of Stomatology, University Hospital Center Zagreb

The purpose of this study was to determine and analyze the type of jaw trauma on exhumed bodies from mass and individual graves located on the occupied areas during the Homeland War in Croatia from 1991 to 1995. Post mortal documentation of the orofacial region of 1068 victims exhumed from mass graves in Croatia was analyzed. The presence of trauma was analyzed for the entire sample as it was for the individual mass graves. The trauma frequency was analyzed individually. Descriptive statistical analysis was done where the $p<0.05$ was considered statistically significant. From 1068 exhumed bodies, $332(31.1 \%)$ presented fractures of the mid and lower face. Fractures of the lower portion of the facial bones were more common (28.1\%). Statistical significance was found in age and trauma freqency relations. $34.6 \%$ of fractures were found in the group $<30$ years of age, $34.2 \%$ in the group $30-60$ years and $21.3 \%$ of fractures were in the group $>60$ years of age. Less fractures were found in females no matter if the subjects presented osteoporotic changes. The results of this study indicate that younger subjects and subjects in their mid ages were more tortured than older subjects. Jaw fractures indicate that the subjects were tortured before they were killed. In female subjects, the fractures were the result of falling in the grawe or from an impact of body on body in grave.

02 WHIPLASH INJURIES OF TEMPOROMANDIBULAR JOINT Irina Filipović Zore ${ }^{1}$, Aljoša Matejčić2 ${ }^{2}$ Zvonimir Zore ${ }^{3}$, Asja Ćelebić ${ }^{4}$ ${ }^{1}$ Department of Oral Surgery, ${ }^{2}$ Department of Traumatology, ${ }^{3}$ Department of onkoplastic surgery, ${ }^{4}$ Department of Removable Prosthodontics, ${ }^{1,2,4}$ School of Dental Medicine, University of Zagreb, ${ }^{1,4}$ Department of Stomatology, University Hospital Centre Zagreb, ${ }^{2,3}$ University Hospital Center ,Sisters of Mercy", Zagreb

Whiplash is defined as an injury that is a consequence of a sudden movement of the head in forward and backward direction. The injury is predominantly located in the upper portions of the neck region, especially the soft tissues of the neck. The whiplash also sometimes affects the temporomandibular joint (TMJ). This type of injury is usually a consequence of a traffic accident where acceleration-deceleration motion takes place. It can also originate from falling on icy surface or other sport related accidents. The injury is related to sudden distortion of the neck with subsequent strain of the soft tissue, muscles, nerves and blood vessels. TMJ being the functional unit of the neck vertebrae, it suffers the internal damage as well. During hyperextension movement, the mouth is opened with subsequent condyle and disc hyper translation resulting in damage of the soft tissue posterior to the joint disc. During deceleration movement, that is hyper flexion, the mouth is shut and the condyles are forced back into the glenoid fossa whereas the disc remains in the anterior position. We present 15 patients referred by the trauma surgeon after confirming 
traumatskog cervikalnog sindroma uputio na pregled oralnom kirurgu, kao i 20 pacijenata koji su zbog senzacija u zglobu (bolnost, zakočenost, škljocanje) samoinicijativno tražili pomoć kod oralnog kirurga, a anamnestički se utvrdilo da su imali trzajnu ozljedu vratne kralježnice. Sve ozljede dogodile su se u prometu. Svi pacijenti obrađeni su ambulanto; anamnestickki, kliničkim pregledom i radiološki. Kod svih bolesnika prepoznato je nešto od poremećaja u TMZ-u i/lil žvačnoj muskulaturi. Najčešće manifestacije bile su bolnost u području zgloba, recipročno škljocanje i zakočenost čeljusti („,losed lock“).

\section{TRAUMA ZUBA}

Jakša Grgurević

Klinika za kirurgiju lica, čeljusti i usta, KB Dubrava, Stomatološki fakultet, Sveučilište u Zagrebu

Traumatske ozljede zubi klasificirane su po mnogim autorima. Najprihvaćenija i kod nas korištena klasifikacija je SZO koju su kasnije modificirali Andreasen, Garcia-Godoy i Ellis. Za oralne i maksilofacijalne kirurge su zanimljive one ozljede koju uzrokuju jaku bol i koje treba što prije sanirati da se bolesniku omogući normalna prehrana. U tu skupinu ozljeda spadaju komplicirane ozljede tvrdih zubnih tkiva, što podrazumjeva otvorenu zubnu pulpu. Veličina otvora zubne pulpe i vrijeme izloženosti pulpe vanjskim utjecajima utječu na postupak s pulpom. Ozljede potpornih struktura zuba, parodonta i alveolarne kosti, iziskuju brzu intervenciju zbog mogućih komplikacija od loše reponiranog zuba, ankiloze zuba pa do gubitka zuba. Da bismo postavili ispravnu dijagnozu i pružili adekvatno liječenje potrebno je svakog bolesnika s ozljedom orofacijalne regije temeljito klinički pregledati i radiološki obraditi.

\section{KRANIOFACIJALNI PRIJELOMI}

Naranđa Aljinović Ratković, Koraljka Hat

Klinika za kirurgiju lica, čeljusti i usta, KB Dubrava, Medicinski fakultet, Sveučilište u Zagrebu

Problem: frakture baze lubanje i ostale frakture kranijuma povezane sa frakturama ličnih kostiju zahtijevaju multidisciplinarnu preoperativnu procjenu i planiranje kako bi kirurški zahvat polučio optimalni funkcijski i estetski rezultat. Simultani neurokirurški i maksilofacijalni kirurški zahvati kontroverzna je metoda jer sam zahvat dugo traje i postoji rizik intrakranijske infekcije. Cilj: pregledni rad ishoda inicijalnih multidisciplinarnih kirurǩkih zahvata. Materijali i metode: od 1996. do 2012. kraniofacijalne frakture uz komplikacije nerokranija zabilijžene su u 10\% slučajeva kod pacijenata sa prijelomima srednjeg lica. U tom razdoblju od 4578 zbrinutih fraktura lica, 1948 su bile fracture srednjeg lica uz ozljede neurokranije kod 193 pacijenta. 38\% pacijenta pretrpjelo je frakturu medijalnog dijela baze lubanje, $42 \%$ pacijenata pretrpjelo je frakturu svoda lubanje dok je $20 \%$ pacijenata pretrpjelo frakturu lateralnih kraniofacijalnih struktura. Prednji medijalni dio baze lubanje (lamina cribriformis, sphenoidal roof) i frontal squama su najčešce zahvaćeni dijelovi. Lateralne kraniofacijlane frakture najčešće su zahvaćale krov orbite i frontotemporalni spoj kao i lateralni dio prednjeg dijela baze lubanje. Kod svih pacijenata multidisciplinarni pristup uključivao je pregled od strane neurokirurga (procjena cerebralne ozljede), oftalmologa (procjena očne ozljede) i radiologa (po mogućnosti MSCT). Lezija olfaktornog živca bila je česta pojava kod pacijenata sa prednjim središnjim frakturama. Kod pacijentat sa prednjim lateralnim frakturama baze primjećene su ozljede očnog živca sa ispadima u bulbomotorici. Terapija $i$ ishod: Kod pacijenata sa lezijama dure i/ili sa intrakranijalnim ozljedama prvo se pristupalo neurokirurškom zahvatu. Sljedeći korak bio je nepropusno zatvaranje kranio-facijalnog spoja sa perikranijalnim režnjem. Nakon toga slijedi rekonstrukcija frakture lica. Pozicioniraje fiksacijskih pločica i imedijatnih koštanih presadaka ovisi o vrsti frakture (nivo, oštećenje kosti itd.). Komplikacije pri kirurškim zagvatima bile su sljedeće: upala ovojnica (1\%), zaostatni telekantus (2.5\%), zaostatni enoftalmus ili malpozicija očne jabučice (7\%) te unakaženost lica (7\%). Najčešći sekundarni zahvati bili su operacija nos, kirurška korekcija enoftalmusa te korekcija ožiljaka. Samo je kod jednog pacijenta zabiljě̌ena rana reoperacija. Zaključak: Prema našem iskustvu rani kirurški zahvati rekonstrukcije kosti kranijuma i lica u jednoj fazi ne povećavaju rizik od infekcija ili pogoršanja neurološkoh ishoda. Fiksacija baze lubanje ključan je zahvat koji omogućuje zadovoljavajuću rekonstrukciju lica.

05 PROTOKOL LIJEČENJA PRIJELOMA DONJE ČELJUSTI U OB KARLOVAC OD 2009. - 2013.

Gvozdan Vukašin ${ }^{1}$, Bojan Fanfani² ${ }^{2}$ Srđan Ante Anzić ${ }^{2}$, Maja Mekovec ${ }^{1}$, Ivan Bažant ${ }^{1}$

${ }^{1}$ Odsjek za maksilofacijalnu i oralnu kirurgiju, ${ }^{2}$ Odjel za otorinolaringologiju, OB Karlovac

Uvod: Tretman i liječenje pacijenata s prijelomom donje čeljusti mijenjalo se i evoluiralo zadnjih desetljeća, ali usprkos protokolu kontroverze postoje oko idealnog pristupa prema svakom pojedinom prijelomu donje čeljusti. Tretman ovisi o puno faktora, o pacijentu, the diagnosis of traumatic cervical syndrome. Other 20 patients came in for an examination voluntarily after suffering from painful sensations in the joint (pain, stiffness, clicking). Medical history revealed that they previously suffered from whiplash. All of the injuries were caused by traffic accidents. All the patients underwent clinical and radiological examination. They were all diagnosed with some sort of TMJ or masticatory muscles disorders. Most common complaints were painful sensations in the joints, reciprocal clicking and locked jaw (,closed lock").

\section{TOOTH TRAUMA}

Jakša Grgurević

Department of Maxillofacial and Oral Surgery, University Hospital Dubrava, School of Dental Medicine, University of Zagreb, Zagreb

Traumatic tooth injuries have been classified by many authors. The most common classification is the WHO one that was later modified by Andreasen, Garcia-Godoy and Ellis. The most interesting injuries for oral and maxillofacial surgeons are the ones that are the most painful so that the surgeon can alleviate the pain and allow the patient to function normally. This group of injuries consists of complicated injuries of hard dental tissue with opened pulp. The size of the pulpal exposure and the exposure time dictate the therapeutic procedure. Periodontal injuries demand immediate attention due to possible complications raging from bad repositioning, root ankylosis or tooth loss. In order to establish the correct diagnosis and offer adequate therapy, every clinician must treat every orofacial injury with thorough attention and radiological follow up.

\section{CRANIOFACIAL FRACTURES}

Naranđa Aljinović Ratković, Koraljka Hat

University Hospital Dubrava, Department of Maxillofacial and Oral Surgery,

School of Medicine, University of Zagreb

Problem: Cranial base fractures or other cranial fracture associated with facial fractures usually demand multidisciplinary preoperative assessment and planning of surgery for optimal functional and aesthetic result. Simultaneous neurosurgical and maxillofacial treatment was long controversial because of long lasting operations and possible risk of the intracranial contamination. Aim: the survey of outcomes after multidisciplinary initial surgery. Material and methods: From 1996.-2012 craniofacial fractures with neurocranium involvement were observed in $10 \%$ of patients with midface fractures. In that period out of 4578 treated facial fractures 1948 were midface fractures, with cranial involvement in 193 patients. 38\% had a dominant medial cranial base fracture, $42 \%$ had a dominant cranial vault fracture and $20 \%$ had lateral craniofacial fracture. Anterior medial cranial base (lamina cribriformis, sphenoidal roof) and frontal squama were most frequently involved. Lateral craniofacial fractures usually involved orbital roof and frontotemporal junction as well as lateral part of the anterior cranial base. In all patients the multidisciplinary preoperative assessment included neurosurgeon (assessment of cerebral injury), ophthalmologist (assessment of ocular injury) and radiologist (preferable MSCT scanning). The lesion of olfactory nerve was frequent observation in anterior central fractures, and ocular nerves damage with motility disturbances in lateral anterior base fractures. Treatment and outcomes: In patients with the dural lacerations or/and intracranial injury neurosurgical treatment was performed at the beginning of surgery, the second step was waterproof closure of cranio-facial junction with pericranial flap and only then the facial fracture was reduced and fixed. The plate positioning and immediate bone grafting depended on the fracture type (level, extent of bone comminution etc.). The surgical complications were: meningeal infection (1\%), residual telecanthus $(2.5 \%)$, residual exophthalmos or eye bulb malposition (7\%) and facial disfigurement (7\%). Most frequent secondary procedures were rhinoplasty, surgical correction of late exophthalmos and scar revision. Only one patient had an early revision. Conclusion: According to our experience early single-stage repair of cranial and facial injury does not increase risk of infection or worsening of the neurological outcome. The fixation of cranial base is a key to adequate facial restoration.

05 MANEGEMENT AND TREATMENT PROTOCOL OF MANDIBULAR FRACTURES AT GENERAL HOSPITAL KARLOVAC

Gvozdan Vukašin ${ }^{1}$, Bojan Fanfani² ${ }^{2}$, Srđan Ante Anzić ${ }^{2}$, Maja Mekovec ${ }^{1}$, Ivan Bažant ${ }^{1}$

${ }^{1}$ Division of Maxillofacial and Oral Surgery, ${ }^{1,2}$ Department of

Otorhinolaryngology, General Hospital Karlovac

Introduction: Treatment and cure of mandibular fractures have changed, evaluated and improved over past decades, but despite better technical equipment and protocols some controversial still remain. The purpose of this study is to evaluate treatment of mandibu- 
godine, denticija, kvaliteta kosti, svijesnost pacijenta, udružene ozljede itd. i vrsti prijeloma. Svrha studije jest da evaluira liječenje prijeloma donje čeljusti u OB Karlovac. Pacijenti i metode: liječili smo 39 pacijenata s ukupno 64 prijeloma donje čeljusti. Muških pacijenata bilo je 29, a ženskih 10. Najmlađi pacijent bio je star dvije, a najstariji sedamdeset četiri godine. Po etiologiji, najčšćce su ozljede izazvane i nastale u prometu dok nasilje i pad imaju isti postotak učestalosti. Kod višestrukih prijeloma gotovo uvijek je postojao prijelom artikularnog nastavka mandibule pa je prema tome to najcešća lokalizacija prijeloma mandibule bez obzira javlja li se u pojedinačnom ili višestrukom prijelomu. Svim pacijentima obavezno je napravljen ortopanogram, Rtg snimka sinusa i kraniogram, a kada to nije bilo moguće napravljen je CT snimak. Rezultati: Sve pacijente koji su imali prijelom artikularnog nastavka donje čeljusti bilo da su jednostruki ili udruženi liječili smo intermaksilarnom fiksacijom (IMF), nismo nikad radili otvorenu repoziciju i osteosintezu zglobnog nastavka. IMF smo radili i kod politraumatiziranih pacijenata koji nisu mogli iz nekog razloga biti operirani unutar dva - tri dana od ozljede. Sve pacijenti koji su imali prijelom druge lokalizacije mandibule osim zglobne, lijecili smo operativno otvorenom repozicijom i osteosintezom pločicom (titan). Pacijentima smo IMF kada je to bilo potrebno, držali 7 - 14 dana ovisno o pacijentu i vrsti prijeloma. Svi pacijenti koji imaju evidenciju o postoperacijskom praćenju nisu imali nikakovih ranih postoperacijkkih komplikacija (osim parestezije mentalisa) niti su u kasnijem praćenju izražavali tegobe okluzalne prirode, a utrnutost mentalisa se sa protokom vremena izgubila. Nismo imali niti jedan slučaj infekcije (obavezno propisan antibiotik u operativnom protokolu). Cijeljenje prijeloma uredno. Zaključak: Smatramo da je liječenje prijeloma mandibule otvorenom repozicijom i osteosintezom metoda izbora za sve lokalizacije prijeloma osim zglobne, a kada imamo i prijelom zglobnog nastavka intermaksilarna fiksacija na period od 7 - 14 dana dala je zadovoljavajuće rezultate u zbrinjavanju takovih pacijenata.

\section{OZLJEDE MEKIH ČESTI GLAVE I VRATA \\ Ivica Lukšić \\ Klinika za kirurgiju lica, čeljusti i usta, KB Dubrava, Medicinski fakultet, Sveučilište u Zagrebu}

Ozljede mekih česti glave i vrata mogu biti izolirane ili udružene s ozljedama donje čeljusti, srednjeg lica te zubi. Izolirane ozljede mekih česti mogu biti otvorene, zatvorene i ogrebotine koje su ograničene samo na epidermis i nemaju kirurški značaj osim kao mogući izvor sekundarnih infekcija. Otvorene ozljede mogu biti perforirajuće, penetrirajuće, avulzijske i rane s defektom tkiva dok se prema sredstvu ozljedivanja dijele na čitav niz različitih vrsta rana. Posebne vrste rana su operacijske, termične (smrzline, opekline) i kemijske rane (kiseline, lužine). Čimbenici važni za cijeljenje rana su infekcija, ishemija tkiva, dob, lokalizacija rane, metabolički poremećaji (dijabetes, hipoalbuminemija), lijekovi (kortikosteroidi, citostatici, hormoni, antikoagulansi) i dr. Učestalost izoliranih ozljeda mekih česti glave i vrata znatno je veća od evidentirane, estetske posljedice često su značajnije od funkcijskih, često je nepotpuna medicinska dokumentacija i znatan su sudskomedicinki problem. Iz nedostatne dokumentacije o ozlijeđenima ne mogu se postaviti standardi i primjeniti suvremeni algoritmi u zbrinjavanju ozlijeđenih, nije moguća kontrola kvalitete u zbrinjavanju ozlijedenih niti utvrditi postupke potrebne da bi se stanje popravilo. Za zanstvanu i stručnu analizu ozljeda, izradu algoritama liječenja, posebice politraumatiziranih bolesnika neophodan je nacionalni sustav trauma registra odnosno kartona ozljeđenika kojeg još uvijek nemamo u svakodnevnom radu.

\section{OSNOVE VJEŠTAČENJA OZLJEDA LICA, USTA, ČELJUSTI I ZUBA Željko Orihovac}

Klinika za kirurgiju lica, čljusti i usta, Klinička bolnica Dubrava, Medicinski fakultet, Sveučilište u Zagrebu

Činjenica je da je lice najizloženiji dio ljudskoga tijela i najvažniji fzički pokazatelj naše osobnosti. Ozljede mekih tkiva lica i usta, kao i viscerokranija te ozljede zubala, imaju često za posljedicu kombinirane funkcionalno-estetske deformitete. Zbog toga je nerijetko vrlo teško razlučiti u kojoj se mjeri kod poslijetraumatskih deformiteta ove regije radi samo o poremećaju funkcije, poremećaju funkcije i izgleda ili isključivo o naruženosti. Zbog specifičnosti regije u anatomskom, funkcionalnom i estetskom pogledu prikazati će se osnove vještačenje ozljeda lica, usta, čeljusti i zuba. Posebno su razmatrani fizička bol, umanjenje životne aktivnosti, naruženost i potreba za tuđom pomoći i njegom kao najvažnije sastavnice vještačenja. Naglašena je važnost medicinske dokumentacije kao i činjenice da se u Republici Hrvatskoj posljednjih godina povećao broj tužbenih zahtjeva protiv liječnika. lar fractures in past four years. First of all, the treatment depends on many different circumstances such as patient's gender, age, dentition, quality of a fractured bone, polytrauma status, type and site of the fracture etc. Patients and methods: We treated 39 patients; some of them had multiple fractures which mean 64 mandibular fractures in 29 men and 10 women. The youngest patient was two years old and the oldest seventy four. The most frequent causes of trauma are traffic accidents and then falls and violence have the same rate. In almost all multiple mandibular fractures condylar process was involved which means that condylar fractures are the most frequent site of trauma. We X-ray every patient, panoramic view and excentric X-ray of the head, and if that is not possible we do CT scan. Results: All patients who sustained condylar fractures, whether they were single or multiple fractures, we treated by conservative method maxillomandibular fixation for around 10-14 days, which means that we did not operate on condyle and we did not do any of rigid fixations for condylar fracture. All the other sites of mandibular fractures, except coronoid process, were treated by operation, open reduction and bone fixation with mandibular 2.0 titanium mini-plates and 2.0 titanium screws. The average period from the injury until the operation was two to three days. We did not experience any postoperative complications, except occasionally mental nerve disturbance, which would disappear in three months' time. No malfunction of occlusion, no infections nor delay in healing process. Conclusion: Based on this retrospective study, we think that operation - open reduction and fracture fixation is a method of choice for all locations of fracture except the condylar fracture. Despite controversial, the conservative treatment, maxillomandibular fixation for condylar fracture, still remains the best.

\section{INJURIES OF THE SOFT TISSUES OF THE HEAD AND NECK} Ivica Lukšić

Department of Maxillofacial and Oral Surgery, University Hospital Dubrava, School of Medicine, University of Zagreb

Injury of the soft tissues of the head and the neck can be isolated or associated with injuries to the lower jaw, mid face and teeth. Isolated injury of the soft tissues may be open, closed or a scratch. Scratches are limited to the epidermis and do not have surgical significance except as a possible source of secondary infections. Open injuries can be perforating, penetrating, and avulsion wounds with tissue defects while according to the sort of injury divided into a number of different types of wounds. Special types of wounds are operating, thermal (frostbite, burns) and chemical wounds (acids, alkalis). Wound healing depends on factors such as infections, ischemia, age, location of the wound, metabolic disorders (diabetes, hypoalbuminemia), drugs (corticosteroids, cytotoxic drugs, hormones, anticoagulants) etc. Isolated soft tissue injuries of the head and the neck are more frequent than recorded, aesthetic consequences are often more important than function, medical records are often incomplete and have considerable forensic-medicine problems. Due to the lack of documentation of injuries, standards are impossible to set and implement modern algorithms in the care of injured, you cannot control the quality of care for injured or establish procedures necessary to remedy the situation. For scientific and medical analysis of injury, making treatment algorithms, especially for polytraumatized patients, national trauma registry system is necessary, but you still do not have those records in their daily work.

\section{BASICS OF EXPERT MEDICAL WITNESS TESTIMONY OF} INJURIES TO FACE, MOUTH, JAWS AND TEETH

\section{Željko Orihovac}

Department of Maxillofacial and Oral Surgery, University Hospital Dubrava, School of Medicine, University of Zagreb

The fact is that the face is one of the most exposed parts of the human body and the most important physical indicator of our personality. The injuries to soft tissues of the face and mouth as well as viscerocranium and dental injuries often result in combined functional and aesthetic deformities. Therefore it is often very difficult to discern to which extent a certain posttraumatic deformity of the region can be treated only as function disorder, function and appearance disorder or exclusively as a case of disfigurement. Due to specific features of the region in the anatomical, functional and aesthetic aspects, basics of expert medical witness testimony of injuries to face, mouth, jaws and teeth will be presented. Special attention has been paid to physical pain, decrease in everyday activities, degree of disfigurement and the individual's need for assistance and care as to the most important components of expert medical witness testimony. The importance of medical documentation has been emphasized as well as the importance of the fact that in the Republic of Croatia there has been an increasing number of lawsuits against doctors in recent years. 
08 MAKSILOFACIJALNA TRAUMA U KBC SPLIT POSLJEDNJIH ČETVRT STOLJEĆA - PRONALAŽENJE I ANALIZA TRENDOVA Saša Ercegović, Njegoslav Bušić, Ante Mihovilović

Odjel za maksilofacijalnu kirurgiju, KBC Split

Autori su analizirali operirane bolesnike s maksilofacijalnom traumom u KBC Split u posljednjih 25 godina. Bolesnici su razvrstani u skupine ovisno o vrsti prijeloma. Prikazan je način liječenja. Uspoređeni su rezultati prve i druge polovine analiziranog razdoblja. Ukupan broj i vrste prijeloma nisu se promijenili. U drugoj polovini analiziranog razdoblja rigidna osteosinteza u potpunosti je zamijenila nestabilnu, odnosno titanijske mini pločice i mrežice su postale jedini osteosintetski materijal. Uočen je porast broja intraoralnog puta aplikacije osteosintetskog materijala, kao i broj pločica po bolesniku. U drugom analiziranom razdoblju osobito je uočljiv značajno povećan broj fraktura orbite, što je rezultat liberalnijeg pristupa upotrebi sofisticiranih dijagnostičkih tehnika. Evidentan je agresivniji stav prema traumi općenito, odnosno povećava se omjer operiranih prema konzervativno liječenim bolesnicima.

09 USPOREDBA KLINIČKIH PARAMETARA JEDNOSTRUKIH I DVOSTRUKIH PRIJELOMA DONJE ČELJUSTI

Naranđa Aljinović Ratković, Marijan Dobranić

Klinika za kirurgiju lica, čeljusti i usta, KB Dubrava, Medicinski fakultet, Sveučilište u Zagrebu

Poznato je da gotovo polovina bolesnika pri ozljedi donje čeljusti uslijed bimehaničkih svojstava mandibule razvije dvostruki prijelom. Cilj ispitivanja je bila usporedba kliničkih parametara u bolesnika s jednostrukim i dvostrukim prijelomima donje čeljusti. Analizirani su podaci bolesnika koji su liječeni od početka 2004. do kraja 2012. godine. Udio dvostrukih prijeloma je bio $42 \%$, a jednostrukih $49 \%$, preostali su imali višestruke prijelome. Nisu uočene značajne razlike u dobi, u obje grupe $2 / 3$ bili su mladi od 30 godina. Udio žena bio je proporcionalno veći u skupini jednostrukih prijeloma (M:Ž 3,8:1 u jednostrukih; 5,6:1 u dvostrukih). Najveća je razlika bila u prometnoj etiologiji: gotovo polovina pacijenata s jednostrukim prijelomima bili su biciklisti i motoristi, a među dvostrukim prevladavali su vozači automobila i putnici u automobilima. Među jednostrukim prijelomima prevladavala je lokalizacija na angulusu, a među dvostrukim na simfizi, u obje grupe kondil je bio tek treći po učestalosti. Nešto više lijevo smještenih prijeloma bilo je među jednostrukim prijelomima (51\%:48\%). Udruženih prijeloma srednjeg lica bilo je gotovo dvostruko više u pacijenata s dvostrukim prijelomima (13\%:7\%), te je $18 \%$ bolesnika s dvostrukim prijelomima bilo hospitalizirano duže od 8 dana naspram $12 \% \mathrm{~s}$ jednostrukim prijelomima. Najveće su razlike zapažene u izboru liječenja: konzervativno je liječeno 30\% pacijenata s jednostrukim prijelomom, a tek $7 \%$ pacijenata s dvostrukim prijelomom. Reoperacija, uključivo odstranjenje pločica, učinjena je u 17\% jednostrukih i $29 \%$ dvostrukih prijeloma. Prema našoj studiji možemo zaključiti da postoje razlike u etiologiji, udruženim prijelomima i izboru liječenja između slučajeva prijeloma mandibule na samoj jednoj ili na dvije lokalizacije.

010 MOGUĆNOSTI PRIMJENE 3D SIMULACIJSKOG PROGRAMA U MAKSILOFACIJALNOJ KIRURGIJI - HRVATSKA VERZIJA

Koraljka Hat, Karlo Obrovac, Naranđa Aljinović Ratković

Klinika za kirurgiju lica, čeljusti i usta, KB Dubrava, Medicinski fakultet, Sveučilište u Zagrebu

\section{O11 FRAKTURE ZIGOMATIČNE REGIJE - LIJEČENJE TIJEKOM ZADNJIH} PET GODINA U OB ZADAR

Mladen Srzentić1 ${ }^{1}$ Ivan Baraka ${ }^{1}$, Zoran Kranjěec ${ }^{2}$, Ivica Nekić ${ }^{2}$, Milan Rudić2 Neven Skitarelić

${ }^{1}$ Odsjek za maksilofacijalnu kirurgiju, ${ }^{1,2}$ Odjel za otorinolaringologiju, $O B$ Zadar

Jagodične kosti čine tzv zigomatični kompleks i najprominentnije su mjesto na licu. Osim što čine laterani i gotovo donji rub orbite, sastavni su dio donje i lateralne stjenke orbite. Samim položajem izložene su traumi, vrlo često frakturi. Obično se uzrokom izoliranih fraktura smatra fizička sila koja dolazi s bočne strane. $S$ obzirom na građu kosti (tijelo i tri nastavka -frontalni, maksilarni i temporalni), smjer djelovanja sile, te pomak kosti izvršena je i podjela fraktura na : one koji dislociraju kost oko vertikalne odnosno horizontalne osovine,izolirane frakture luka te kominutivne frakture tijela kosti koje nastaju izuzetno jakom silom na ograničeno mali prostor. Osim standardnih kliničkih simptoma i klasične radiološke obrade, u dijagnostici fraktura uveliko pomaže MSCT kosti lica s rekonstrukcijom istih.Ova pretraga uvedena je kao standardno pravilo dijagnostike. Osim što je učinila je daleko komfornijom dijagnostiku i liječenje fraktura jagodičnih ko-
08 MAXILLOFACIAL TRAUMA IN THE CLINICAL HOSPITAL CENTER SPLIT IN THE LAST QUARTER CENTURY - THE DISCOVERY AND TREND ANALYSIS

Saša Ercegović, Njegoslav Bušić, Ante Mihovilović

Department of Maxillofacial Surgery, University Hospital Center Split

The authors analyzed the operated patients with maxillofacial trauma at Clinical Hospital Center Split in the last 25 years. Patients were divided into groups depending on the type of fracture. Featured is a method of treatment. The results of the first and second half of the period were analyzed. Total number and types of fractures did not change. In the second half of the analyzed period rigid osteosynthesis completely replaced the unstable osteosynthesis, respectively titanium mini plates and mats have become the only osteosynthetic material. The study showed that intraoral way of application of osteosynthetic materials was increased, as well as number of plates per patient. In the second analyzed period, the number of blowout orbital fractures was significantly increased as a result of more liberal approach to the use of sophisticated diagnostic techniques. Aggressive attitude toward trauma in general is evident, i.e. the ratio of surgically treated patients to conservatively treated ones is increased.

09 COMPARISON OF CLINICAL PAREMETRS WHEN DEALING WITH SINGLE AND DOUBLE MANDIBULAR FRACTURES

Naranđa Aljinović Ratković, Marijan Dobranić

Department for Maxillofacial and Oral Surgery, University Hospital Dubrava, School of Medicine, University of Zagreb

It is a known fact that almost half of the patients suffering the mandibular injury develop a secondary mandibular fracture due to the bimechanical properties of the mandible. We analyzed the patient data collected during the period from 2004 till 2012. Double fractures accounted for $42 \%$ and single fractures accounted for $49 \%$ of the fractures. The rest of the fractures were multiple mandibular fractures. We did not notice significant differences in age. In both groups $2 / 3$ of the patients were under 30 years of age. Women experienced more single fractures than men (W:M = 3.8:1 in single: 5.6:1 in double fractures). The biggest difference was in the traffic etiology: more than halve of the patients with single fracture were motorcyclist or bike cyclists. Patients with double fractures were car drivers and passengers. Single fractures were mostly localized on the mandibular angle while double fractures were mostly located on the mandibular symphisis. In both groups the condyle was on the third place. Single fractures slightly favored the left side of the mandible (51\%:48\%). Mid face fractures were twice as common with the patients experiencing double mandibular fractures (13\%:7\%). 18\% of the patients with double fractures were hospitalized longer than 8 days versus $12 \%$ experiencing single fracture. The largest difference was observed in treatment choice: $30 \%$ of the patients with single fracture were treated conservatively, versus only $7 \%$ of the patients with double fracture. Secondary operation for the purpose of removing the fixation plates was done in $17 \%$ of the cases for single and 29\% for double fractures. According to our study we can conclude that there are differences between etiology, multiple fractures and treatment choice between single and double mandibular fractures.

\section{O10 THE POSSIBILITES OF USING 3D SIMULATION SOFTWARE IN} MAXILLOFACIAL SURGERY

Koraljka Hat, Karlo Obrovac, Naranđa Aljinović Ratković

Department of Maxillofacial and Oral Surgery, University Hospital Dubrava, School of Medicine, University of Zagreb

\section{FRACTURES OF THE ZYGOMATIC COMPLEX - TREATMENT} DURING THE LAST FIVE YEARS IN THE GENERAL HOSPITAL IN ZADAR

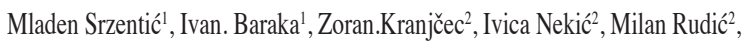
Neven Skitarelić ${ }^{2}$

${ }^{l}$ Division of Maxillofacial Surgery, ${ }^{1,2}$ Department of Otorhinolaryngology, General Hospital Zadar

Malar region, zygomatic complex, is the most prominent place on the face. It's positionis is very exposed to injury, often fractures. Although, is part of the lateral and the lower frame of the orbit, it is also an integral part of the lower and lateral orbital walls. Usually, the cause of isolated fracture is considered as a natural force that comes from the side. Given the position and structure of the bone, the direction of force and displacement of the bone, the fractures are divided to: those who dislocate the bone around the vertical or horizontal axis, isolated fractures of zygomatic arch and comminuted fracture of the corpus of the zygomatic bone.Comminuted fracture of the corpus are induced with extremly strong force limited on small area. In addition to standard clinical symptoms and classic radiographic examination, the diagnosis of fracture greatly helps MSCT (multislice computer tomography) with reconstruction of facial bones. It's introduced as stan- 
stiju, pokazala je i prisutnost fraktura dna orbite odnosno lateralne stjenke maksile zajedno s frakturom jagodičnih kosti. Liječenje fraktura varira od podizanja i repozicije jagodične kosti kukom, do osteosinteze, ne baš davno žicom, a danas orbitalnim pločicama i vijcima. Osteosinteza se obično radi na dva mjesta (frontozigomatična sutura; donji rub orbite). U razdoblju od 1.1. 2008 do 30.4. 2013. godine liječeno je ukupno 42 bolesnika s izoliranom frakturom jagodičnih kosti. Od tog broja kod 16 pacijenata je jagodična kost bila reponirana s kukom, dok je kod 26 bolesnika primjenjena osteosinteza kao metoda liječenja. Zabiljě̌ene su 3 izolirane frakture luka jagodične kosti koje su reponirane po Gillesu. Dvije frakture ograničene su samo na tijelo kosti /kominutivne/, a liječene su ostesintezom. U petogodišnjem presjeku vidljivo je da se kao oblik liječenja novijeg datuma preferira osteosinteza, u odnosu na repoziciju kukom, i to ne samo kod nestabilnih fraktura nakon repozicije kosti kukom. Prihvaćanju novih standarda u opskrbi fraktura svakako doprinosi, osim operativne tehnike, i sve bolji osteosintetski materijal koji omogućuje dobru repoziciju i kompatibilnost u zaraštanju kosti. Glede operativne tehnike subcilijarni pristup ,koji koristimo, osim prikaza kosti omogućuje i inspekciju dna orbite. Ono zna biti ledirano i kod fraktura jagodične kosti, a što nam otkriva suvremena radiološka dijagnostika, MSCT. Eksploracija dna orbite rađena je kod 5 bolesnika. Kod 3 bolesnika rađena je plastika dna orbite, radi veličine defekta, usprkos normalnoj bulbomotorici. Prikaz fronto- zigomatične suture, rezom u obrvi, ujedno omogućuje i repoziciju kosti Dingmanovom metodom, ali i luka, ukoliko je frakturiran. Ova metoda korisna je kod repozicije kosti koja prethodi osteosintezi. Iako repozicija kukom ima svoje indikacije i dobre rezultate sve više prevladava osteosinteza kao metoda liječenja fraktura zigomatične regije.

\section{NOVE MOGUĆNOSTI U LIJEČENJU NEURALGIJE N.} TRIGEMINUSA

Dubravka Šepić-Grahovac ${ }^{1}$, Mirna Juretić ${ }^{2}$

${ }^{2}$ Poliklinika Interneuron Rijeka, ${ }^{2}$ Klinika za maksilofacijalnu i oralnu kirurgiju, KBC Rijeka, Medicinski fakultet, Sveučilište u Rijeci

Neuralgija Nervus trigeminusajestanjekronične boli uzrokovano ekstremnim,sporadičnim iznenadnim, palećim bolovima u području lica. Lokalizacija boli je tipična, jedne strane čeljusti ili lica, traje danima, tjednima ili mjesecima. Incidencija TN je 4,3 na 100000 osoba godičnje, česća kod žena, a mnogo češća u starijih osoba.Paroksizmalna osobina bolova i dobar terapijski odgovor na antiepileptike (karbamazepin, valproat, fenitoin , lamotrigin) su karakteristični za ovo stanje ali neželjeni efekti antiepileptika mogu biti veliki problem, osobito u osoba starije životne dobi. Primjena pregabalina (PGB) u bolesnika sa TN koja nema pozitivan odgovor na uobičajenu medikamentoznu terapiju (analgetika i antiepileptika) se opisuje u brojnim kliničkim studijama (nekoliko prospektivnih „open label"). PGB (dnevna doza od 150-600 mg) reducira intenzitet boli i učestalost napadaja, smanjuje simptome anksioznosti i depresije, te poboljšava spavanje. Shodno našem iskustvu PGB u bolesnika koji pate od TN se dobro podnosi, nema većih neželjenih pojava i općenito poboljšava kvalitetu života tih osoba.

\section{ZNAČENJE PSIHOLOŠKIH ČIMBENIKA U RAZVOJU ZLOĆUDNIH TUMORA USNE ŠUPLJINE I OROFARINIKA \\ Daniela Petrić ${ }^{1}$, Mirna Juretic ${ }^{2}$ \\ ${ }^{1}$ Klinika za psihijatriju, ${ }^{2}$ Klinika za maksilofacijalnu i oralnu kirurgiju, \\ Medicinski fakultet, Sveučilište u Rijeci, ${ }^{1,2} \mathrm{KBC}$ Rijeka,}

Uvod: Utjecaj psiholoških čimbenka kod ovisnika o alkoholu i razvoja zloćudnog tumora usne šupljine i orofarinksa gotovo je potpuno meostražen. Ovo istraživanje pretpostavlja važnost obrambenih mehanizama, crta osobnosti i korišstenja strategija suočavanja u formiranju psihosomatskog odgovora. Cilj: Istražiti rane obiteljske relacije, korištenje mehanizama obrane, crte osobnosti, stilove suočavanja i razinu stresa u bolesnika oboljelih od zloćudnog tumora usne šupljine i orofarinksa, koji su ujedno ovisnici o alkoholu, u odnosu na ovisnike o alkoholu i zdravu populaciju. Ispitanici i postupci: U istraživanju je sudjelovalo 79 bolesnika, ovisnika o alkoholu koji su oboljeli od zloudnog tumora usne šppljine i orofarinksa, od čega je 51 bolesnik zadovoljio uključne kriterije.Istraživanje je provedeno na Klinici za maksilofacijalnu kirurgiju u KBC Rijeka u periodu 2005.-2009.g. Ujednacene usporedne skupine bile su ovisnici o alkoholu i zdrava populacija. Provedena je psihijatrijska anamneza i MINI (Mini International Neuropsychiatric Interview) upitnik. Ispitanici u ispunili opći demografski nestandardizirani upitnik, Upitnik životnog stila i obrambeni mehanizmi (ŽS), Profil indeksa emocija (PIE), Upitnik stilova suočavanja sa stresnim situacijama (COPE) i Ljestvicu životnih događaja

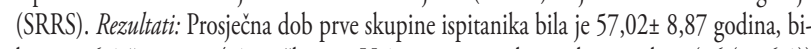
lo je 21,6\% žena i 78,4\% muškaraca. Većina je ispitanika imala je srednju $(36(70,6 \%))$ ili nižu $(13(22,5 \%))$ stručnu spremu. Ispitne skupine su značajno razlikovale po teškom djetinjstvu $(\mathrm{p}<0,001)$ uz zlostavljanje $(\mathrm{p}=0,004)$. Ovisnici o alkoholu oboljeli od zloćudnog tumora usne šupljine i orofarinksa znatno su manje koristili primitivne obra- dard diagnostic rule. In addition, MSCT makes more comfortable treatment of fractures, showing the presence of fracture, orbital floor and lateral wall of maxilla. Treatment of fractures varies from repositioning the bone with hook to osteosynthesis. Osteosynthesis, until recently, with wire and today with mini plates and screws. It's performed usually on two places(frontozygomatic suture and lower edge of the orbit). In the period from last five years in General hospital in Zadar were treated a total of 42 patients with fractures of zygomatic bone. Of this number, 16 patients were treated by reposition of the bone with hook, while in 26 patients is performed osteosynthesis as method of treatment. We observed 3 isolated fractures of zygomatic arch that we treated by Gilles's metod. Two fractures were comminuted fractures of the corpus of the zygomatic bone, and were treated with osteosynthesis.In five year section can be seen that as form of treatment for recent prefers osteosynthesis, in relation to the repositioning of the hook, and not only in unstable fractures after repositioning with hook. Adoption of new standards in the treatment of fractures certainly contributes, except surgical techniques, and better osteosynthetic material that provides good reduction and compatibility in bone healing.Regarding operative techniques subciliar approach, which we use except the display bone allows inspection the floor of the orbit. It can be injuried with fractures of zygomytic bone, which reveals modern radiologic MSCT. Exploration of the floor of the orbit was performed in 5 patients.In 3 patients underwent plastic of the floor of the orbit, because of size of the defect was large, despite normal moving of the eyeball. Showing fronto-zygomatic suture, with eyebrow incision, also allows repositioning zygomatic bone and arch with Dingman method.This metod is useful for repositioning bones preceding osteosynthesis. While repositioning the hook has its indications and good results more prevalent osteosynthesis as treatment metods of fracture in the zygomatic complex.

\section{SOME NEW ASPECTS IN THE TREATMENT OF TRIGEMINAL NEURALGIA \\ Dubravka Šepić-Grahovac ${ }^{1}$, Mirna Juretić2}

${ }^{l}$ Policlinic Interneuron Rijeka, ${ }^{2}$ Department of Maxillofacial and Oral Surgery, University Hospital Center Rijeka, School of Medicine, University of Rijeka

Trigeminal neuralgia (TN) is a chronic pain condition that causes extreme, sporadic, sudden burning face pain. The pain is typically felt on one side of the yaw or cheek and can last for days, weeks or months. The overall incidence rate is 4.3 per 100000 persons per year, higher for women and is much higher in the elderly. The paroxysmal nature of pain and it response to antiepileptic drugs are characteristic but sometimes the side effects of antiepileptic drugs (carbamazepine, valproic acid, phenytoin, lamotrigine) can be a big problem, especially in the elderly. The effects of pregabaline (PGB) in patients with refractory $\mathrm{TN}$ to previous drug therapy are well documented in several prospective open label studies. PGB (150-600 mg daily) reduced baseline intensity of pain and attack frequen$c y$, anxiety and depression symptoms decreased and improved sleep. According to our experience PGB in patients suffering from TN is well tolerated, without serious side effects and improved their quality of life.

\section{THE ROLE OF PSYCHOLOGICAL FACTORS IN DEVELOPMENT OF ORAL AND OROPHARYNGEAL CANCER}

Daniela Petrić ${ }^{2}$, Mirna Juretic ${ }^{2}$

${ }^{1}$ Department of Psychiatry, ${ }^{2}$ Department of Maxillofacial and Oral Surgery, School of Medicine, University of Rijeka, ${ }^{1,2}$ University Hospital Center Rijeka

Introduction: Influence of psychological factors in alcoholics with oral and oropharyngeal cancer has barely been explored. The hypothesis in this research is that defense mechanisms, personality traits and the use of coping strategies have considerable importance in formation of psychosomatic response. Aim: To examine early family relations, personality traits, the use of defense mechanisms, coping styles and the level of stress in alcohol dependent patients diagnosed with oral and oropharyngeal cancer, compared to alcohol dependent persons without malignant tumors and healthy population. Participants and methods: The research h included 79 alcohol dependent persons diagnosed with malignant tumor of the oral cavity and oropharynx, of which 51 satisfied the research inclusion criteria. The research was conducted at the Maxillofacial Clinic, University Hospital Center Rijeka, Croatia, from 2005. to 2009. The matching control groups consisted of alcoholics and healthy population. We established the history of psychiatric diseases and applied the Mini International Neuropsychiatric Interview. Participants also corresponded to a general demographic non-standardized questionnaire, the Revised Questionnaire of Life Style and Defense Mechanisms, the Profile Index of Emotion (PIE), the COPE Questionnaire and the Social Readjustment Rating Scale (SRRS). Results: The first group of participants had the mean age of $57.02 \pm 8.87$ years; $21.6 \%$ were women and $78.4 \%$ men. Majority of the participants had secondary (36 (70.6\%) or primary education $(13(25.5 \%))$. The research groups showed significant differences relating to difficult childhood $(\mathrm{p}<0.001)$ including abuse $(\mathrm{p}=0.004)$. Alcohol dependent participants suffering from oral and or pharyngeal cancer significantly less frequently used 
ne: regresiju ( $\mathrm{p}=0,004)$, i premještanje ( $\mathrm{p}=0,0013)$, a ovisnici o alkoholu više su koristili neurotske obrane: kompenzacija $(\mathrm{p}=0,005)$ i intelektualizaciju $(\mathrm{p}<0,001)$. Statistički značajna razlika između tri grupe ispitanika nađena je na slijedećim varijablama: reprodukcija $(\mathrm{F}=3,356 ; \mathrm{p}=0,038)$, inkorporacija $(\mathrm{F}=4,377 ; \mathrm{p}=0,014)$, opozicionalnost $(\mathrm{F}=5,941$; $\mathrm{p}=0,003)$ i bias (pristranost) ( $\mathrm{F}=4,517 ; \mathrm{p}=0,012)$. Najniže rezultate na varijabli agresivnosti postigla je prva skupina. Statistički značajna razlika dobiven je na faktoru 3 gdje ispitanici iz prve $(M=52,90 \pm 14,06$., $\mathrm{p}=0,010) \mathrm{i}$ ispitanici iz druge skupine $(\mathrm{M}=52,90 \pm 12,37$; $\mathrm{p}=0,048)$ postižu značajno višse rezultate od ispitanika iz treće skupine $(\mathrm{M}=45,16 \pm 16,75)$. Analiza stresnih dogadaja pokazala je statistički značajne razlike ( $\mathrm{F}=3,602 ; \mathrm{p}=0,030)$. Ispitanici iz druge skupine $(M=265,69 \pm 177,00)$ postižu statistički značajno više rezultate od ispitanika iz treće skupine $(\mathrm{M}=188,04 \pm 146,34 ; \mathrm{p}=0,008)$. Zaključak: Rezultati istraživanja pokazuju važnu ulogu psiholoških čimbenika u razvoju zloćudnih tumora usne šupljine i orofarinksa multifaktorijalnoj etiopatogenezi te bolesti.

Ključne riječi: Ovisnost o alkoholu; Psihodinamika; Psihosomatska bolest; Tumori, zloćudni, glave i vrata; Tumori, zloćudni, usne šupljine i orofarinksa

\section{OKULO-FACIO-KARDIO-DENTALNI (OFCD) SINDROM}

Dragana Gabrić Pandurić1 ${ }^{1}$ Bernarda Lozić ${ }^{2}$, Iselin Saltvig ${ }^{3}$, Kerstin Kutsche ${ }^{3}$,

Tatjana Zemunik ${ }^{4}$,Hrvoje Brkićl

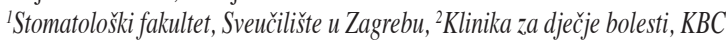
Split, ${ }^{4}$ Medicinski fakultet, Sveučilište u Splitu

Okulo-facio-kardio-dentalni (OFCD) sindrom je rijetka X-vezana dominantna bolest, koja se uglavnom manifestira kod žena i koju prati niz oftalmoloških, facijalnih, kardioloških i dentalnih anomalija. Genske analize su pokazale da je heterozigotna mutacija na BCOR genu odgovorna za nastanak ovog sindroma. Prikazana je obitelj s 4 ženska člana zahvaćena OFCD sindromom (baka, majka i monozigotične ženske blizanke). Dokazana je visoka intrafamilijarna fenotipska varijabilnost, s posebnim naglaskom na kardiološka i oftalmološka obilježja, sa sve ozbiljnijim manifestacijama u sukcesivnim generacijama. Kliničkim i radiološkim pregledom nađena je rijetka dentalna anomalija talon cusp na gornjem desnom trajnom incizivu kod majke monozigotičnih blizanki. Ovo je prvi nalaz, prema recentnoj literature, ove rijetke dentalne anomalije kod pacijenata s OFCD sindromom i de novo mutacijom na BCOR genu.

\section{KIRURŠKO LIJEČENJE RASCJEPA - PRIMARNO OBLIKOVANJE NOSA \\ Predrag Knežević \\ Klinika za kirurgiju lica, čeljusti i usta, KB Dubrava, Stomatološki fakultet, Sveučilište u Zagrebu}

Korekcija nosa u sklopu rascjepa usne sastavni je dio kirugije rascjepa usne. Unatrag nekoliko desetljeća pristup primarnoj korekciji nosa istovremeno s plastikom usnice, u dobi od 3-6 mjeseci, sve je „radikalniji““. Postoperativni rezultati sve su bolji, a tehnike koje se koriste nemaju utjecaja na rast i razvoj lica, što je potvđeno i dugogodišnjim praćenjem. Opseg deformacije nosa sigurno ovisi o opsegu rascjepa usne i alveolarnog grebena tako da je pristup u primarnoj korekciji različit i uvijek individualan. Tri su osnovna čimbenika koji utječu na oblik nosa u skopu jednostranih rascjepa primarnog nepca: mišícni „nesklad“ rascijepljenih mišića, koštana hipoplazija gornje čeljusti i asimetrija koštane „podloge“. Alarna hrskavica na strani rascjepa histološki se ne razlikuje u odnosu na alarnu hrskavicu nerascijepljene strane. Njen tipičan oblik na rascijepljenoj strani usnice rezultat je „promijenjenih“ sila rascijepljenih mišića usnice, a ne primarne malformacije hrskavice. Koštani „manjak“ maksile na strani rascjepa te devijacija vomera dodatni su čimbenici koji utječu na oblik nosa. Kontrakcije rascijepljenih mišića usnice te polazišta mišića na bazi septuma i kolumeli nerascijepljene strane dovode do karakterističnog izgleda nosa kod potpunuih, širokih jednostranih rascjepa primarnog nepca: - nosnica rascijepljene strane je proširena u vodoravnom smjeru i spuštena niže i straga u odnosu na nerascijepljenu stranu, - alarna hrskavica je spuštena i proteže se duž rascijepa usnice, - nosni vršak je usmjeren na nerascijepljenu stranu, - kolumela je kraća na strani rascjepa i koso usmjerena bazom smještenom na nerascijepljenoj strani, - spina nasalis anterior okrenuta je ka nerascijepljenoj strani. Postoji više tehnika, kako kirurških tako i pretkirurških za što bolje oblikovanje nosa kod jednostranih rascjepa usnice. Pretkirurške - ortodontske metode koriste ortodontske pločice s ekstenzijama u vestibulumu nosa radi „usmjeravanja “ rasta nosa. Kirurške metode podrazumijevaju prikazivanje mišića, repoziciju i sidrenje na periostu gornje čeljusti te korišstenje silikonskih „nosnih umetaka“ postoperativno. Reinsercija mišića kod opsežnih rasjepa usnice i pridružene deformacije nosa ne mora bitno utjecati na definitivni rezultat oblikovanja nosa. U ovim slučajevima važno je repozicioniranje nosnoga krila i oblikovanje alarnih hrskavica. Oslobađanje i transponiranje nosnoga hrskavičnog septuma, odizanje dna nosa na strani rascjepa te istovremeno obli- primitive defense mechanisms of regression ( $\mathrm{p}=0.004)$ and displacement $(\mathrm{p}=0.013)$ compared to alcoholics without malignant tumors, who significantly more often used neurotic defense mechanisms - compensation ( $\mathrm{p}=0.005)$ and intellectualization $(\mathrm{p}=0.001)$. The three groups of participants showed statistically significant differences in the following variables: reproduction $(\mathrm{F}=3.356 ; \mathrm{p}=0.038)$, incorporation $(\mathrm{F}=4.377 ; \mathrm{p}=0.014)$, oppositionality $(\mathrm{F}=5.941 ; \mathrm{p}=0.003)$ and bias $(\mathrm{F}=4.517 ; \mathrm{p}=0.012)$. As for aggression variable, the first group had the lowest scores. Furthermore, the groups significantly differed in factor 3 - the first group $(M=52.90 \pm 14.06 ; \mathrm{p}=0,010)$ and the second group of participants $(\mathrm{M}=52.90 \pm 12.37 ; \mathrm{p}=0.048)$ had significantly higher scores than the third group $(\mathrm{M}=45.16 \pm 16.75)$. The analysis of stressful events also showed statistically significant differences $(\mathrm{F}=3.602 ; \mathrm{p}=0.030)$. The second group had statistically higher scores than the third group ( $M=265.69 \pm 177.00 ; M=188.04 \pm 146.34 ; \mathrm{p}=0.008)$. Conclusion: The research results suggest that psychological factors have an important role in development of oral and oropharyngeal cancer and its multifactorial etiopathogenesis.

Key words: alcohol dependence, psychodynamics, psychosomatic disease, tumors, malignant, head and neck, tumors, malignant, oral and oropharyngeal

\section{OCULO-FACIO-CARDIO-DENTAL (OFCD) SYNDROME}

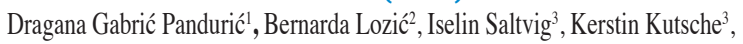

Tatjana Zemunik ${ }^{4}$, Hrvoje Brkićl

${ }^{1}$ School of Dental Medicine, University of Zagreb, ${ }^{2}$ Department of Pediatrics,

University Hospital Centre Split, ${ }^{4}$ School of Medicine, University of Split

Oculo-facio-cardio-dental (OFCD) syndrome is a rare X-linked disorder mainly manifesting in females. Patients show ocular, facial, cardiac, and dental abnormalities. OFCD syndrome is caused by heterozygous mutations in the BCOR gene, located in Xp11.4, encoding the BCL6 co-repressor. We report a Croatian family with four female members (grandmother, mother and monozygotic female twins) diagnosed with OFCD syndrome who carry the novel BCOR mutation c.4438C >T (p.R1480*). They present high intrafamilial phenotypic variability with special regard to cardiac defect and cataract that showed more severe disease expression in successive generations. Clinical and radiographic examination of the mother of the twins revealed a talon cusp involving the permanent maxillary right central incisor. This is the first known report of a talon cusp in OFCD syndrome with a novel mutation in the BCOR gene.

Key words: OFCD syndrome; $B C O R$ gene; Talon cusp; Intrafamilial phenotypic variability

\section{PRIMARY SURGICAL CLEFT LIP/NOSE REPAIR Predrag Knežević}

Department of Maxillofacial and Oral Surgery, University hospital Dubrava, School of Dental Medicine, University of Zagreb

Primary correction of the nasal deformity simultaneously with the definitive lip repair (usually at the age of 3 to 6 months) is a standard procedure of the cleft lip repair. In the last few decades surgical nose correction has become more radical and extensive. Postoperative results after these techniques are much better, a long lasting evaluation showed no influence on the face growth. The volume of cleft nose deformity depends on the volume of the cleft lip and alveolus. That is the reason why individual approach in the surgical primary cleft nose correction is of such importance. Three major factors influence the nasal deformity in both complete and incomplete unilateral clefts: muscle imbalance, skeletal hypoplasia and asymmetry of the skeletal base. There are no histologically significant differences in lower lateral cartilage between cleft and non-cleft side. The typical shape of alar cartilage on the cleft side is the result of deformation caused by abnormal forces from the labial cleft and disrupted muscles, rather than primary cartilage malformation. Skeletal hypoplasia of the upper jaw on the cleft side and vomer deviation are additional factors which influence the shape of the cleft nose. The contraction of the cleft lip muscles, the insertion of the muscle on the base of the septum and columella on the non-cleft side are also the reasons for the typical cleft nose deformity in the complete wide unilateral cleft of the primary palate: - Ala on the cleft side is lengthened vertically and lies below the ala on the non-cleft side, - Lower lateral cartilage is depressed and spread across the cleft, - Nasal tip is deviated toward the no cleft side, - Columella on the cleft side is shortened and obliquely oriented with the base deviated and located in the non-cleft side, - Anterior nasal spine turns toward the noncleft side. There are few techniques, surgical and non-surgical, for as good as possible nose shaping in the unilateral cleft lip and nose. Non-surgical - orthodontic procedures use orthodontic plates with nasal extensions for nasoalveolar molding. In surgical techniques, cleft lip and nasal muscles are reinserted on the anatomical places on the upper jaw and nasal splinting (internal or external) postoperatively is recommended. Proper repair of the muscle during primary lip repair does not necessarily improve the existing nasal deformity in wide clefts. In such cases reposition of the ala and shaping of lower lateral cartilage is important. Septum transposition and deep nose preparation on the cleft side with simultaneously shaping of the vestibule of the nose, and the 
kovanje ne samo vestibuluma nosa nego i „dubljih“ dijelova nosa u primarnom zahvatu važni su za definitivni oblik nosa. Prikazujemo vlastita iskustva i tehnike oblikovanja nosa tijekom primarnog oblikovanja usnice. Kirurškom liječenju rascjepa ne treba pristupati shematski i standardizirano, nego individualno svakom djetetu kako u kirurškom liječenju tako i u vremenu operacije.

\section{KVALITETA ŽIVOTA NAKON KIRURŠKOG ODSTRANJENJA DONJEG UMNJAKA}

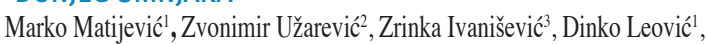
Darko Macan ${ }^{4}$

${ }^{1}$ Medicinski fakultet Osijek, ${ }^{2}$ Učiteljski fakultet, ${ }^{1,2}$ Sveučilište Josipa Jurja Strossmayera u Osijeku, ${ }^{3}$ Privatna ordinacija dentalne medicine, Osijek, ${ }^{4}$ Klinika za kirurgiju lica, čeljusti i usta, Klinički zavod za oralnu kirurgiju, KB Dubrava, Stomatološki fakultet, Sveučilište u Zagrebu

Cilj: Glavni cilj ovoga istraživanja bio je utvrditi u kojoj mjeri detaljan usmeni naputak o postupanju nakon kirurškog odstranjenja donjeg umnjaka, iskustvo operatera, indeks tjelesne mase i pozicija zuba utječu na poslijeoperacijsku kvalitetu života pacijenta. Ispitanic i postupci: Provedeno je istraživanje kvalitete života nakon odstranjenja donjeg umnjaka kod 108 ispitanika. Ovisno o tipu informacije dane svakom ispitaniku posebice, ispitanici su podijeljeni u dvije skupine: ispitnu u kojoj su pacijenti dobili detaljan pismeni i usmeni naputak te kontrolnu skupinu u kojoj su dobili samo pismeni naputak o postupanju nakon operativnoga zahvata. U prvom dijelu istraživanja istražen je utjecaj spola, indeksa tjelesne mase, iskustva operatera i pozicije zuba na intenzitet boli prvih sedam poslijeoperacijskih dana. U drugom dijelu istraživanja ispitana je kvaliteta života korišstenjem modificiranoga OHIP-14 kriterija četvrti, sedmi i trideseti poslijeoperacijski dan ovisno o tipu ranije dane informacije ispitanicima. Rezultati: Rezultati ove studije pokazali su da na intenzitet poslijeoperacijske boli nisu imali utjecaja tip informiranosti, pozicija zuba kao ni indeks tjelesne mase, dok su iskustvo operatera i spol ispitanika utjecali na intenzitet razine poslijeoperacijske boli. Obje skupine izrazile su zadovoljstvo u poslijeoperacijskom razdoblju za pojedine istražene varijable modificiranoga OHIP-14 upitnika, pri čemu se intenzitet i redoslijed glavnih komponenata zadovoljstva koje su odredene analizom glavnih komponenata razlikuje među dvjema ispitivanim skupinama pacijenata. Ispitna skupina četvrti poslijeoperacijski dan imala je najviši stupanj zadovoljstva sa snom, fizičkim izgledom i mogućnošću prehrane. U kasnijem poslijeoperacijskom periodu ispitna skupina (sedmi i trideseti dan) imala je najviši stupanj zadovoljstva s odsutnošću nelagode prì odstranjenju konaca, zadovoljstva obavljenim tretmanom te sposobnošću jela. Zaključak: Detaljne prijeoperacijske usmene upute pacijentima mogu značajno unaprijediti kvalitetu života nakon kiruškoga odstranjenja donjih umnjaka.

Ključne riječi: kvaliteta života, usmeni naputak, donji umnjak, pozicija umnjaka, iskustvo operatera, indeks tjelesne mase

\section{O17 RADIOMORFOMETRIJSKI INDEKSI MANDIBULE KAO} POKAZATELJI OSTEOPOROZE KOD ŽENA U POSTMENOPAUZI Bruno Popić1 , Davorin Đanić2 ${ }^{2}$ Vlatko Kopić1, Marko Matijević ${ }^{3}$, Stjepan Siber ${ }^{1}$, Dražen Dražić ${ }^{1}$

${ }^{1}$ Odjel za maksilofacijalnu kirurgiju, KBC Osijek, ${ }^{2}$ Odjel za bolesti uha, nosa, grla i kirurgiju glave i vrata, OB „Dr. Josip Benčevic“", Slavonski Brod,

${ }^{3}$ Medicinski fakultet, Sveučilište Josipa Jurja Strossmayera u Osijeku

Osteoporoza je najččsća metabolička bolest kosti, koja danas predstavlja značajan javnozdravstveni problem. Bolest se javlja u osoba starije životne dobi, no učestalije kod žena u postmenopauzi. S obzirom na produženje životnoga vijeka i trend starenja populacije za očekivati je epidemijski porast bolesnika s osteoporozom. Osteoporoza se često naziva $i$, thom bolesti „zbog nedostatka simptoma, a kada se jave prijelomi kosti tada je bolest već uznapredovala. Komplikacije bolesti imaju dalekosežne posljedice, kako za pojedinca, tako i za cjelokupnu zajednicu. Pouzdana dijagnostička metoda za osteoporozu je mjerenje mineralne gustoće kosti ili denzitometrija, no ona ne može biti metoda probira za populaciju koja je sklona obolijevanju od osteoporoze. Preduvjeti uspješne metode probira populacije su: široka dostupnost, prihvatljiva cijena koštanja, neinvazivnost što je nužno za sudjelovanje ispitanika. Metoda probira također mora biti dovoljno osjetljiva i zadovoljavajuće specifična kako bi broj lažno pozitivnih rezultata doveli na minimum. Oportuno koristeći redovito snimanje ortopantomograma u ambulantama oralne i maksilofacijalne kirurgije, ovim istraživanjem nastojat će se utvrditi mogućnost ortopantomograma - panoramske snimke čeljusti, kao metode probira za dio populacije koja je rizična ili boluje od osteoporoze. Cilj ove analitičke studije je radiomorfometrijske indekse mandibule izmjerene na ortopantomogramu: (MCW) debljina korteksa mandibule, (PMI) panoramski mandibularni indeksa, (MCI) mandibularnog kortikalni indeks usporediti s: mineralnom gustoćom kosti (BMD) skeleta, OST indeksom, biljezima koštane pregradnje i frakturnim rizikom, u svrhu procjene mogućnosti njihova korišsenja kao pokazatelja deep nasal structure during the cleft lip procedure is important. The personal experience and some techniques are presented during the primary cleft lip repair. Surgical cleft treatment is not schematic and standardized. Each case is specific and unique, and the treatment should be individually oriented in the surgical technique as well as in timing.

\section{QUALITY OF LIFE AFTER SURGICAL REMOVAL OF LOWER WISDOM TOOTH}

Marko Matijević1 ${ }^{2}$ Zvonimir Užarević ${ }^{2}$ Zrinka Ivanišević ${ }^{3}$, Dinko Leović ${ }^{1}$, Darko Macan ${ }^{4}$

${ }^{1}$ Faculty of Medicine, ${ }^{2}$ Faculty of Education, ${ }^{1,2}$ University Josip Juraj Strossmayer, Osijek, ${ }^{3}$ Private Dental Practice, Osijek, ${ }^{4}$ Department of Maxillofacial and Oral Surgery, University Hospital Dubrava, School of Dental Medicine, University of Zagreb

Aim: The main objective of this study was to determine to what extent a detailed verbal instruction about treatment after surgical removal of a lower wisdom tooth, operator's experience, body mass index and the position of wisdom teeth affect postoperative quality of life. Participants and methods: The research on quality of life after removal of a lower wisdom tooth was conducted with 108 patients. Depending on the type of information given to each respondent individually, the examinees were divided into two groups: a test group which was given detailed written and oral instructions, and a control group which received only written instructions about treatment after the surgery. The first part of the study examined the impact of gender, body mass index, operator's experience and the position of teeth on pain intensity during the first seven days after the treatment. The second part of the study examined the quality of life using a modified OHIP-14 criterion four, seven and thirty days after the operation depending on the type of information previously provided to the respondents. Result: The results of this study indicate that the type of information, the position of the teeth and body mass index did not influence the intensity of postoperative pain, whereas operator's experience and gender have an effect on intensity levels of postoperative pain. Both groups expressed satisfaction with the postoperative period for the individual variables investigated in modified OHIP-14 questionnaire, with the intensity and the order of the major components of satisfaction determined by the principal component analysis differing between the two groups of the patients. On the fourth postoperative day, the test group expressed the highest level of satisfaction with sleep, physical appearance and the ability to eat. In the later postoperative period the test group (on the seventh and thirtieth day) had the highest level of satisfaction with the absence of discomfort during removal of sutures, performed treatment satisfaction, and the ability to eat. Conclusion: Detailed preoperative oral instructions to patients can significantly improve the quality of life after operative removal of a lower wisdom tooth. Key words: quality of life, lower wisdom tooth, verbal instruction, operator's experience, body mass index, position of wisdom teeth

\section{RADIOMORPHOMETRIC MANDIBULAR INDICES SERVING AS} OSTEOPOROSIS INDICATORS IN POSTMENOPAUSAL WOMEN Bruno Popić1 , Davorin Đanić ${ }^{2}$, Vlatko Kopić1 ${ }^{1}$, Marko Matijevićc ${ }^{3}$, Stjepan Siber ${ }^{1}$, Dražen Dražić ${ }^{1}$

${ }^{l}$ Department of Maxillofacial Surgery, University Hospital Center Osijek,

${ }^{2}$ Department of Otorhinolaryngology, Head and Neck Surgery, General Hospital „Dr. Josip Benčevic“", Slavonski Brod, ${ }^{3}$ School of Medicine, University „Josip Juraj Strossmayer “, Osijek

Osteoporosis is one of the most common metabolic diseases and it represents a signifcant public health problem. The disease is most common in elderly people, more often in postmenopausal women. With longer life expectancy the disease is taking and epidemic proportions in the population. Osteoporosis is often called the ,silent disease" due to lack of symptoms. When the bone fractures occur, the disease is in the more advanced state. Complications arising from the disease have farfetched consequences for the individual and for the community. Reliable diagnostic method for osteoporosis is bone density measurement or densitometry. This method cannot serve as a screening method in the population that is prone towards osteoporosis. The prerequisites for successful population screening methods are: wide availability, affordable price, noninvasive method. The screening method also has to be sensitive and specific enough to rule out the false positive screenings or at least to minimize such mistakes as much as possible. The use of ortho $\mathrm{x}$-rays for oral and maxillofacial surgery purposes serves as $s$ great starting point for a population screening method. This research will try to determine the possibility of using such $\mathrm{x}$-rays as an osteoporosis screening method. The purpose of this analytical study is to compare the mandibular radio morphometric indices measures using ortho x-ray (MCW - mandibular cortex thickness; PMI - panoramic mandibular index; MCI - mandibular cortex index) with bone mineral density (BMD), OST index, osseous remodeling markers and fracture risk. This comparison is done to assess the possibility of using these indi- 
osteoporoze. Radiomorfometrijski indeksi mandibule su očitani i izmjereni na ortopantomogramima 146 ispitanica u postmenopauzi, životne dobi od 40 do 90 godina. Za sve ispitanice izmjerena je mineralna gustoća kosti (BMD) u području vrata bedrene kosti lumbalne kralježnice (L1-L4) DXA metodom (dvoenergetska apsorpciometrija X zraka). Ispitanice su razvrstane u tri skupine s obzirom na BMD raspodjelu Svjetske zdravstvene organizacije: normalan nalaz, osteopenija i osteoporoza. Analiza ROC krivulje korištena je za određivanje optimalne granične vrijednosti, površine ispod krivulje (AUC), osjetljivosti i specifičnosti za svaki mandibularni indeks u dijagnozi promijenjenog denzitometrijskog nalaza, te razlučivanje osteopenije i osteoporoze. Za ocjenu značajnosti dobivenih rezultata odabrana je razina značajnosti od $\mathrm{p}=0,05$. Kod ispitanica $s$ normalnim nalazom BMD statistički značajno je veći $\mathrm{MCW}(4,6 \mathrm{~mm})$ i PMI $(0,47 \mathrm{~mm})$ u odnosu na ispitanice sa smanjenim BMD, MCW (3,6mm) i PMI (0,36mm) (Mann Whitney test, $p<0,001)$. Kod ispitanica s promijenjenim nalazom denzitometrije (osteopenija / osteoporoza), s obzirom na MCI (erozije korteksa) nalazimo kod osteopenija najviše ispitanica s II. stadijem erozija 69,5\%, dok kod osteoporoze najviše ih je 57,4\% sa III. stadijem erozija ( $\chi^{2}$ test, $\mathrm{p}<0,001)$. Pri razlučivanju normalnog od promijenjenog nalaza denzitometrije za MCW indeks dobivamo AUC 0,862, za MCI indeks AUC 0,826, te za PMI indeks AUC 0,874. Uspoređujući MCW indeks s OST indeksom nalazimo da je značajno širi donji korteks mandibule u ispitanika s niskim OST indeksom, (Kruskal Wallis test, $\mathrm{p}=0,006$ ). Uspoređivanjem PMI indeksa s OST indeksom, značajno višu vrijednost panoramskog indeksa imaju ispitanici niskog OST indeksa (Kruskal Wallis test, $\mathrm{p}=0,015$ ).

Usporedbom MCI indeksa s OST indeksom, značajno više ispitanica iz skupine $s$ visokim OST indeksom pripada skupini s III. stadijem morfološkog indeksa donjeg korteksa mandibule $\left(\chi^{2}\right.$ test, $\left.\mathrm{p}=0,003\right)$. Radiomorfometriijki indeksi MCW i PMI ne mogu se dovesti u korelaciju s biljezima koštane pregradnje, kako s osteokalcinom, tako niti s deoksipiridinolom. Izuzetak je MCI kod kojeg nalazimo značajno više vrijednosti osteokalcina u ispitanika s III. stadijem morfološkog izgleda donjeg korteksa mandibule (Kruskal Wallis test, $\mathrm{p}=0,023)$. $\mathrm{S}$ obzirom na frakturni rizik postoji samo negativna slaba povezanost frakturnog rizika s MCW indeksom (Spearmanov koeficijent korelacije $\varrho=-0,342, p<0,001$ ), dok povezanosti s PMI indeksom nema. S porastom stadija erozija korteksa mandibule (MCI) progresivno raste i frakturni rizik. S obzirom na rezultate, ortopantomogram i radiomorfometrijski indeksi mandibule (MCW, PMI, MCI) mogu se koristiti u kliničkoj praksi kao metoda probira za rano otkrivanje smanjene mineralne gustoće kosti kod žena u postmenopauzi. Maksilofacijalni kirurzi, oralni kirurzi, kao i doktori dentalne medicine stoga imaju važnu ulogu u prevenciji osteoporoze i prijeloma kod starijih osoba.

Ključne riječi: mandibula; menopauza; osteoporoza; radiomorfometrijski indeksi.

\section{REKONSTRUKCIJA A. CAROTIS S VENA SAFENA GRAFTOM Ante Lučev \\ Klinika za maksilofacijalnu i oralnu kirurgiju, KBC Rijeka}

$\mathrm{Na}$ dva primjera prikazana je procedura rekonstrukcije a. carotis comm. i interne $s$ graftom v. safene. Naime, u oba slučaja kod bolesnika s oralnim karcinomom, bilo je potrebno zbog adherentnih metastaza vrata na a. carotis comm. i interni resecirati a. carotis comm. u sklopu proširene disekcije vrata. Moguće posljedice takvog zahvata bez rekonstrukcije a. carotis su poznate i najč̌šće rezultira opsežnim neurološkim deficitom kontralateralne strane tijela.

Cilj navedenih zahvata bio je učiniti radikalan kirurški zahvat sa rekonstrukcijom a. carotis spriječiti nastanak neurološkog deficita. Odluka o rekonstrukciji sa v. safena graftom donesena je zbog niza prednosti u odnosu na neke druge materijale, a naročito zbog dostupnosti, zbog praktički nikakve cijene koštanja i mogućnosti biranja uzimanja grafta sa odgovarajućom širinom lumena žile. Princip rada je timski što podrazumijeva suradnju maksilofacijalnog i vaskularnog kirurga. Vaskularni kirurg se ukljucuje u operacijski zahvat oko sat vremena prije prikaza proksimalnog i distalnog mjesta resekcije a. carotis $\mathrm{i}$ u tom vremenu pronalazi i uzima odgovarajući segment v. safene. Po prikazu a. carotis vaskularni kirurg izvodi anastomoze na obilježenim mjestima i uspostavlja cirkulaciju kroz graft, a u nastavku operacije maksilofacijalni kirurg resecira a. carotis i završava disekciju vrata. U sklopu rekonstrukcije mekih česti vrata primjenjen je muskulokutani pectoralis maior režanj.

U oba slučaja u ranom postoperacijskom periodu kod bolesnika nisu zamijećeni neurološki deficiti. Zbog navedenog smatram da je ova metoda pouzdana i uspješno rješava veliki problem koji proizlazi iz potrebe resekcije a. carotis comm. i interne te je preporučam kao standardnu proceduru u izvođenju ovakvih zahvata.

\section{REKONSTRUKCIJA DEFEKTA ALVEOLARNOG GREBENA MAKSILE UNILATERALNIM OTOČNIM NAZOLABIJALNIM REŽNJEM}

Njegoslav Bušić, Ante Mihovilović, Ivan Šimundža

Odjel za maksilofacijalnu kirurgiju, KBC Split

Uvod: Peteljkasti nazolabijalni režnjevi primjenjuju se za pokrivanje defekata na više lo- ces to screen for osteoporosis. Radio morphometric mandibular indices are measured on ortho x-rays taken from 146 postmenopausal female patients, from 40 to 90 years of age. Bone mineral density (BMD) was measured from the neck of the femur and from the lumbar part of the spine (L1 - L4) using the DXA method. The patients were then sorted out into three groups based on their BMD World Health Organization score: normal mineral density, osteopenia and osteoporosis. ROC curve analysis was used to determine the optimal border values, the area under the curve (AUC), sensitivity and specificity for every mandibular index with altered densitometry screening, and to distinguish between osteopenia and osteoporosis. Value of $\mathrm{p}=0.05$ was used to determine the result significance level. Patients with normal BMD results had statistically significant larger MCW $(4.6 \mathrm{~mm})$ and PMI $(0.47 \mathrm{~mm})$ when comparing to patients with smaller BMD, MCW $(3.6 \mathrm{~mm})$ and PMI $(0.36 \mathrm{~mm})$ (Mann Whitney test, $p<0,001)$. In patients with changed densitometry results (osteopenia/osteoporosis), 69.5\% had level II. erosions (MCI results in patients with osteopenia) while $57.4 \%$ of patients was erosion level III. (MCI results in patients with osteoporosis) $\left(\chi^{2}\right.$ test, $\left.p<0,001\right)$. When distinguishing a normal from changed densitometry results, for $\mathrm{MCW}$ result we get 0.862 , for $\mathrm{MCI}$ index AUC 0.826 and for PMI index AUC 0.874. When comparing MCW index with OST index we find that patients with lower OST index have significantly wider mandibular cortex, (Kruskal Wallis test, $\mathrm{p}=0,006$ ). When comparing $\mathrm{MCI}$ index with OST index, significantly more patients from the high OST index group belong to level III. morphological index of the lower mandibular cortex $\left(\chi^{2}\right.$ test, $\left.\mathrm{p}=0,003\right)$. Radio morphometric indices like $\mathrm{MCW}$ and PMI cannot be correlated with osseous remodeling markers (osteokalcine and deoxipiridonol). The exception is $\mathrm{MCI}$ index where we find much higher values of osteokalacine in patients at level III. state of morphological lower mandibular cortex (Kruskal Wallis test, $\mathrm{p}=0,023)$. There is a negative weak correlation between the fracture risk and MCW index (Spearman coefficient of correlation $\varrho=-0,342, \mathrm{p}<0,001$ ) while there in no correlation with PMI index. The fracture risk progressively increases with the increase of the $\mathrm{MCI}$ index. Based on our results, we can conclude that ortho x-rays and radio morphometric mandibular indices (MCW, PMI, MCI) can be used in clinical practice as a method for early low mineral density detection in postmenopausal women. Maxillofacial and oral surgeons, as well as general dentists have an important role in osteoporosis detection and fracture prevention in elderly people.

Key words: mandible; menopause; osteoporosis; radio morphometric indices

018 RECONSTRUCTION OF ARTERIA CAROTIS USING SAPHENOUS VEIN GRAFT

Ante Lučey

Department of Maxillofacial and Oral Surgery, University Hospital Center Rijeka

Procedure of carotid artery reconstruction (communis and internal) was shown on two examples using saphenous venin graft. In fact, in both cases, in patients with oral cancer, it was necessary to remove internal artery carotid and carotid communis due to adherent neck metastasis by performing extended neck dissection. Possible consequences of that kind of surgery, without reconstruction of carotid artery, are well known and often result in extensive neurological deficit on opposite side of the body. The aim of this surgical procedure was to radically remove tumor tissue with reconstruction of the carotid artery in order to prevent the occurrence of neurological deficits. Saphenous vein graft was used due to a number of advantages; its availability, no increase in surgical costs and possibility of choosing vessel with adequate lumen. The main principle of surgery is a team work of maxillofacial and vascular surgeon. Vascular surgeon is included in surgery an hour before the proximal and distal carotid artery resection and in that time finds and takes the appropriate segment of vena saphena for a graft. Upon depiction of carotid artery, vascular surgeon performs anastomoses at the marked areas and restores circulation through the graft. Subsequently maxillofacial surgeon removes carotid artery and concludes neck dissection. Musculocutaneous flap of pectoralis major is utilized in the reconstruction of the neck soft tissue. In both cases, in the early postoperative period, patients did not have neurological deficits. Therefore I believe that this method is reliable and successfully solves a major problem that arises from the need of carotid artery removal thus I recommend it as a standard procedure in performing extended surgical neck dissection.

\section{RECONSTRUCTION OF MAXILLARY ALVEOLAR RIDGE DEFECTS WITH UNILATERAL ISLAND NASOLABIAL FLAP \\ Njegoslav Bušić, Ante Mihovilović, Ivan Šimundža \\ Department of Maxillofacial Surgery, University Hospital Center Split}

Introduction: Pedicled nasolabial flaps are being used to cover defects in several locations in the oral cavity. Usage of the island nasolabial flap for reconstruction of defects in the 
kalizacija u usnoj šupljini. Uporaba otočnih nazolabijalnih režnjeva za rekonstrukciju defekata na gornjoj čeljusti, alveolarnom grebenu gornje čeljusti i nepcu se izuzetno rijetko spominje u literaturi. Materijal i metoda: U radu je pokazan primjer rekonstrukcije koštano-sluzničnog defekta alveolarnog grebena maksile uzrokovanog ablativnim onkokirurškim zahvatom. Za tu svrhu upotrijebljen je jednostrani otočni nazolabijalni režanj. Rasprava i rezultat: Rekonstrukcija otočnim nazolabijalnim režnjem je tehnički brz i relativno jednostavan kirurški postupak. Poslijeoperacijski oporavak je kratak jer se radi o operaciji u jednom aktu. U pokazanom primjeru nije bilo komplikacija, a estetski i funkcionalni ishod bio je odličan. Zaključak: Unilateralni otočni nazolabijalni režanj omogućuje pouzdanu rekonstrukciju ekscentričnih defekata sluznice alveolarnog grebena gornje čeljusti, kao i za prekrivanje ogoljele kosti i/lil koštanih defekata alveolarnog grebena gornje čeljusti umjerene veličine.

\section{O20 PRIMJENA PREFABRICIRANOG SINTETIČKOG KOŠTANOG BLOKA U AUGMENTACIJSKIM TEHNIKAMA \\ Marko Blaškovićc ${ }^{1}$ Dragana Gabrić Pandurić ${ }^{2}$, Mato Sušíc ${ }^{2}$, Juraj Brozović ${ }^{3}$, Davor Katanec ${ }^{2}$

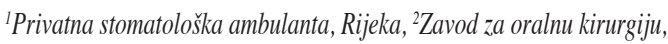 Stomatološki fakultet, Klinika za stomatologiju, KBC Zagreb, ${ }^{3}$ Privatna stomatološka ordinacija, Split}

Upotreba implantata u stomatologiji u drastičnom je porastu tijekom zadnjeg desetljeća. Idealan, trodimenzionalni položaj implantata u kosti preduvjet je optimalne estetike i dugoročne stabilnosti implanto-protetske terapije. U slučaju naglašene resorpcije alveolarnog grebena, implantaciji prethodi kirurški zahvat augmentacije resorbirane kosti. Koštani blokovi predstavljaju sigurnu terapijsku opciju nadoknade izgubljenog vertikalnog i horizontalnog volumena kosti. "Zlatnim standardom" se još uvijek smatra autologni koštani transplantat. Glavni nedostatak ove tehnike je otvaranje drugog kirurškog polja, morbiditet donorskog mjesta i ograničena količina raspoložive kosti. Upotrebom prefabriciranih sintetičkih koštanih blokova moguće je izbjeći navedene nedostatke. Sintetički prefabricirani koštani blokovi se izrađuju u za to posebno opremljenim i pripremljenim strojevima, na osnovi prethodne obrade CBCT-a i preciznog planiranja morfologije i veličine koštanog bloka prema modelu trodimenzionalne snimke. Prednost navedene tehnike je idealno prilijeganje koštanog nadomjeska u planirano područje augmentacije, kao i ugodnost za pacijenta. Sintetički prefabricirani koštani blokovi slijede sve kirurške principe fiksacije i zatvaranja koji se koriste kod autolognog koštanog transplantata. Osnovni nedostatak ove suvremene tehnike je skupoća planiranja i izradbe koštanog nadomjeska. Prikazan je slučaj 34-godišnjeg pacijenta s gubitkom prvog gornjeg desnog premolara zbog uzdužne frakture korijena zuba, po čijoj ekstrakciji zaostane značajan koštani defekt. Učini se augmentacija tehnikom prefabriciranog sintetičkom koštanog nadomjeska, a 6 mjeseci po kirurškom zahvatu se ugradi dentalni implantat.

\section{O21 AUTOTRANSPLANTACIJA ZUBA. ZABORAVLJEN ILI} ZAPOSTAVLJEN POSTUPAK

${ }^{1}$ Hrvoje Buntak, Irina Filipović Zore'2, Mato Sušić ${ }^{2}$

'Privatna stomatološka ambulanta, ${ }^{2}$ Zavod za oralnu kirurgiju, Stomatološki

fakultet, Sveučilište u Zagrebu, Klinika za stomatologiju, KBC Zagreb

Suvremena medicina u nadomjestcima tkiva i organa, kad god je to moguće, potiče uporabu vlastitih tkiva i organa. Tako je danas Republika Hrvatska u samom europskom vrhu po transplantacijama solidnih organa. Suvremena pak dentalna medicina nedostatke zuba rješava protetskim i implantoprotetskim rješenjima pomalo zanemarujući autologne zubne zametke. Sedamdesetih godina prošlog stoljeća vé su dokazani pozitivni učinci autotransplantacija zuba kako u nadoknadi izgubljenih zuba, tako i u stimulirajućem odnosu na rast i razvoj čeljusti. Danas je dokazano da je osim toga zametak zuba najveći i najbolji izvor matičnih stanica tako da transplantacijska i reparacijska medicina nikako ne bi smjela zapostavljati i tu činjenicu. U radu se prikazuje dokle se je stiglo sa spoznajama o autotransplantacijama zuba, te se kroz prikaze slučajeva ističe i taj postupak kao terapeutsku mogućnost, pogotovo kod starije djece i adolescenata gdje je uporaba dentalnih implantata kontraindicirana.

\section{O22 USPOREDBA INCIDENCIJE ODONTOGENIH UPALNIH I} RAZVOJNIH CISTA

Josip Matkovićl ${ }^{\prime}$ Kristijan Novački², Tihomir Kuna ${ }^{3}$

${ }^{1}$ Ordinacija dentalne medicine, Baška Voda, ${ }^{2}$ Ordinacija dentalne medicine, Krapina

${ }^{3}$ Zavod za oralnu kirurgiju, Stomatološki fakultet, Sveučilišste u Zagrebu, Klinika za stomatologiju, KBC Zagreb

Odontogene ciste su patološke šupljine odontogenog podrijetla ispunjene tekućinom ili polutekućim sadržajem, a okružene su vanjskom vezivnom i unutrašnjom epitelnom upper jaw, alveolar ridge of the upper jaw and palate is very rarely mentioned in the literature. Materials and methods: In this paper is presented an example of reconstruction of bone-mucosal maxillary alveolar ridge defect caused by oncosurgical ablative procedure. For that purpose, the unilateral island nasolabial flap was used. Discussion and result: Reconstruction with naslolabial island flap is technically quick and relatively simple surgical procedure. Postoperative recovery is short because it is a single act operation. In the case shown, no complications were found and the aesthetic and functional outcome was excellent. Conclusion: Unilateral island nasolabial flap provides reliable reconstruction of eccentric mucosal defects of the alveolar ridge of the upper jaw, as well as the cover for the bare bone and/or bone defects of the alveolar ridge of the upper jaw of moderate size.

\section{O20 THE USE OF PREFABRICATED SYNTHETIC BONE GRAFT IN AUGMENTATION TECHNIQUES}

Marko Blaškovićl ${ }^{\text {, Dragana Gabrić Pandurić2 }}$, Mato Sušić2 , Juraj Brozović ${ }^{3}$, Davor Katanec ${ }^{2}$

${ }^{\text {P} P r i v a t e ~ d e n t a l ~ p r a c t i c e, ~ R i j e k a, ~}{ }^{2}$ Department of Oral Surgery, School of Dental Medicine, Department of Stomatology, University Hospital Centre Zagreb,

${ }^{3}$ Private dental practice, Split

The use of dental implants has increased drastically over the last decade. Ideal implant placement in the bone is the prerequisite for optimal esthetics and long term implant stability. In case of substantial alveolar ridge resorption, the procedure that precedes implantation is alveolar ridge augmentation. Bone grafts present a safe therapeutic option for vertical and horizontal ridge augmentation. Autologous bone transplant is considered to be the „golden standard“. The shortage for this procedure is secondary op. site, morbidity of the donor site and limited supply of osseous material. Using the prefabricated synthetic osseous graft one can avoid all the pre mentioned negative aspects. Synthetic prefabricated osseous graft are manufactured in specifically equipped and prepared machines based on the three dimensional CBCT scan. The graft morphology and size are determined exactly based on the 3D scan. The advantage of such method is the ideal fit of the osseous graft on the augmented field. When working with synthetic osseous grafts, one must follow the same surgical guidelines already established for the autologous grafts. The main drawback for this method is the procedural cost and the cost of graft fabrication. In this case report we presented a 34 year old patient who experienced the loss of first upper right premolar due to vertical root fracture followed by post extraction osseous defect. Synthetic osseous graft was used to augment the defect followed by implant placement 6 months after the augmentation procedure.

\section{O21 AUTOLOGOUS TOOTH IMPLANTATION, FORGOTTEN OR} NEGLECTED PROCEDURE

${ }^{1}$ Hrvoje Buntak, Irina Filipović Zore ${ }^{2}$, Mato Sušić ${ }^{2}$

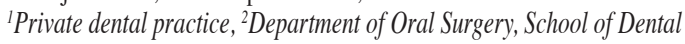

Medicine, University of Zagreb, Department of Stomatology, University

Hospital Centre Zagreb

Modern medicine emphasizes the use of autologous organs and tissues whenever it is possible. The Republic of Croatia is one of the top leaders in solid organ transplantation. Modern dental medicine on the other hand emphasizes the use of prosthetic and implantprosthetic solutions when dealing with missing teeth, often neglecting the autologous teeth germs. During the 70's many positive effects of autologous tooth implantation were noticed when replacing missing teeth. The same effect was noticed in stimulated growth and jaw development. It is known today that tooth germ is the most valuable source of stem cells, a fact that should not be neglected by the researchers in transplant and regenerative medicine. This paper summarizes the latest breakthroughs in autologous tooth implantation and through series of case reports emphasizes this procedure as a therapeutic possibility especially with older children and adolescents where the use of dental implants is contraindicated.

\section{O22 COMPARISON OF INCIDENCE OF OCCURENCE OF} ODONTOGENIC INFLAMARORY AND DEVELOPMENTAL CYSTS Josip Matković1 ${ }^{1}$ Kristijan Novački² ${ }^{2}$ Tihomir Kuna ${ }^{3}$

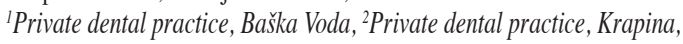

${ }^{3}$ Department of Oral Surgery, School of Dental Medicine, University of Zagreb, Department of Stomatology, University Hospital Centre Zagreb

Odontogenic cysts are pathogenic hollows with odontogenic origin filled with liquid or semiliquid content. They are surrounded with external and internal epithelial connective tissue. This research involved retrospective insight from January 1st, 2007 until De- 
ovojnicom. U istraživanju smo retrospektivno u razdoblju od 1.siječnja 2007. do 31. prosinca 2010. godine u KBC Zagreb i Stomatološkoj poliklinici u Splitu pratili pojavu upalnih i razvojnih odontogenih cista. Sve cistektomije odnosno enukleacije cista vršene su u lokalnoj anesteziji. Tijekom 4 godine liječeno je 747 pacijenata od toga 396 u KBC-u u Zagrebu i 351 u Stomatološkoj poliklinici u Splitu. Podatci o pacijentima obrađeni su s obzirom na dijagnozu , lokalizaciju ( gornja i donja čeljust ), distribuciju po spolu i dobi te zahvaćenost zubi. Većina odontogenih cista bila je radikularna u obje navedene ustanove. Razlika između ove dvije ustanove jest da je u KBC-u u Zagrebu bilo više pacijenata s dijagnozom rezidualne ciste (32) od onih s razvojnom, tj. folikularnom cistom (10), dok je u Stomatološkoj poliklinici u Splitu taj odnos bio obrnut (17:13) što je uvelike utjecalo na ukupni rezultat gdje su rezidualne ciste na drugom mjestu po pojavnosti. Još jedna razlika između ove dvije ustanove jest to da je u Stomatološkoj poliklinici u Splitu bilo više muških pacijenata s dijagnozom odontogene ciste, dok je u ukupnom odnosu te u KBC-u u Zagrebu bilo više žena. U obje ustanove je veća pojavnost cista u gornjoj čeljusti i cista zahvaća većinom jedan zub. Razlika između prosječne dobi između dvije navedene ustanove je statistički značajna.

\section{O23 METASTAZA ADENOKARCINOMA BUBREGA NA NEPCU}

Juraj Brozović1 ${ }^{1}$ Dragana Gabrić Pandurić2 ${ }^{2}$, Mato Sušić ${ }^{2}$, Marko Blašković3

Sven Seiwerth ${ }^{4}$, Davor Katanec ${ }^{2}$

'Privatna stomatološka ordinacija, Split, ${ }^{2}$ Zavod za oralnu kirurgiju,

Stomatološki fakultet, Sveučilište u Zagrebu, Klinika za stomatologiju, KBC

Zagreb, ${ }^{3}$ Privatna stomatološka ambulanta, Rijeka, ${ }^{4}$ Zavod za patologiju,

Medicinski fakultet, Sveučilište u Zagrebu

Karcinomi bubrega rijetko rezultiraju metastazama u području glave i vrata. Metastatski potencijal pokazuju paranazalni sinusi, parotidna žlijezda, oko, orbita, unutarnje uho, zvukovod, mandibula te u iznimno rijetkim slučajevima nepce. Diferencijalno dijagnostički, na nepcu se mogu pojaviti i planocelularni karcinom, adenoidcistični i adenokarcinomi, limfomi te rijetke neoplazme poput melanoma, sarkoma te plazmocitoma. Potrebna je temeljita dijagnostička obrada u pogledu CT-ova te MRI-ova uz obvezatnu biopsiju palatinalnih lezija. Prikazan je slučaj 80-godišnjeg pacijenta sa solitarnom metastazom adenokarcinoma bubrega na središnjem dijelu tvrdog nepca porijeklom iz karcinoma svijetlih stanica bubrega te su opisane njegove recidivirajuće epizode.

\section{PRIMARNI EKSTRANODULARNI NHL USNE ŠUPLJINE}

Kristijan Novački ${ }^{1}$, Tihomir Kuna ${ }^{2}$, Irina Filipović Zore ${ }^{2}$, Dragana Gabrić Pandurić ${ }^{2}$

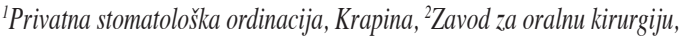

Stomatološki fakultet, Klinika za stomatologiju, KBC Zagreb

Non-Hodgkin limfomi (NHL) su heterogena skupina limfoproliferativnih neoplazmi što ih obilježava pojava maligno promijenjenih limfocita u limfnome čvoru, a rjede primarno u drugim organima. Maligni su limfomi u usnoj šupljini rijetki i čine približno 3.5\% svih malignih promjena u oralnoj regiji. Prikazana su dva bolesnika s primarnim ekstranodularnim NHL-om usne šupljine, prvi s primarnom manifestacijom NHL-a na gingivi, a drugi s istim nalozom u postekstrakcijskoj alveoli koja nije cijelila. Na temelju histološkog i imunohistokemijskog nalaza se postavi konačna dijagnoza difuznog velikostaničnog limfoma B-imunofenotipa. Nakon kombinacije radioterapije i kemoterapije, kod pacijenata se postigla potpuna remisija te su se povukli svi klinicki znakovi bolesti. Dijagnosticiranje ekstranodularnog limfoma čeljusti je izazov, jer gotovo uvijek postoji sumnja na malignu tvorbu, a često je prikriven oralnim i dentalnim patološkim stanjima. Rano otkrivanje malignih limfoma usne šupljine je proporcionalno povezano s uspjehom liječenja.

\section{O25 INTRAORALNI ADENOIDNI CISTIČNI KARCINOM: KORELIRA} LI PRISUTNOST PERINEURALNE INVAZIJE S VELIČINOM PRIMARNOG TUMORA, LOKALNOM INVAZIJOM, KIRURŠKIM RUBOVIMA, UDALJENIM METASTAZAMA I ISHODOM BOLESTI Kristijan Dinjar ${ }^{1}$, Ivica Lukšíc ${ }^{2}$

${ }^{1}$ Odjel za maksilofacijalnu kirurgiju, KBC Osijek, ${ }^{2}$ Klinika za kirurgiju lica, čeljusti i usta, KB Dubrava, Medicinski fakultet, Sveučilište u Zagrebu

Adenoidni cistični karcinom ili cylindroma je najčešći zloćudni tumor malih žlijezda slinovnica. Karakterizira ga spor rast, perinuralno širenje bolesti, hematogene presadnice tri puta češce od limfogenih, udaljene presadnice bez regionalnog širenja bolesti i doživotno pračenje bolesnika. Cilj ovoga istraživanja bio je ispitati povezanost perineuralnog širanje bolesti sa veličinom tumora, lokalnim širenjem bolesti, pozitivnim kirurški rubovima, udaljenim presadnicama i ishod u bolesnika sintraoralnim cilindromom malih žlijezda slinovnica. Istraživanje je provedeno na ukupno 44 bolesnika Klinike kirurgiju lica, čeljusti i usta KB Dubrava u razdoblju od 1984. do 2008. godine, a koji su bolovali od intraoralnog cilindroma malih žlijezda slinovnica. Dobivene rezultate usporedili smo s rezultati- cember, 31st, 2010 where all the cases involving odontogenic inflammatory and developmental cysts were monitored and recorded. Facilities of interest were KBC Zagreb and Dental clinic in Split. All surgical procedures involving cysts were done in local anesthesia. During this four year period, 747 patients were treated. 396 in KBC Zagreb and 351 in Dental clinic Split. Patient data were processed taking into regard the diagnosis, location (upper or lower jaw), sex distribution and teeth involvement. Most of the odontogenic cysts were associated with tooth radix in both facilities. The difference between the two facilities is that in KBC Zagreb there were more patients with residual cysts (32) than with the developmental i.e. follicular cyst (10), whereas in Dental clinic in Split the ratio was inverse (17:13). This greatly influenced the overall result placing the residual cysts in the second place. Another difference between these two facilities is in the sex distribution where in Split there were more male patients diagnosed with odontogenic cysts where in Zagreb there were more women. In both facilities the predominant cyst location was in the upper jaw with only one tooth affected. The difference in the average age between the two facilities was statistically significant.

\section{O23 PALATAL METASTASIS OF KIDNEY ADENOCARCINOMA}

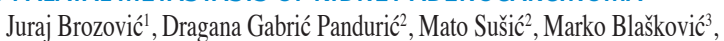
Sven Seiwerth ${ }^{4}$, Davor Katanec ${ }^{2}$

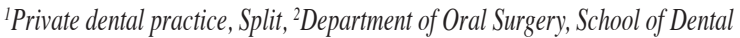

Medicine, University of Zagreb, Department of Stomatology, University

Hospital Centre Zagreb, ${ }^{3}$ Private dental practice, Rijeka, ${ }^{4}$ Department of

Pathology, School of Medicine, University of Zagreb

Kidney carcinoma rarely metastasizes in the head and neck region. Metastatic potential is observed in paranasal sinuses, parotid gland, eye, orbit, inner ear, meatus, mandible and rarely palate. Differential diagnosis includes squamous cell carcinoma, adenocystic and adenocarcinoma, lymphoma and rare neoplasm like melanoma, sarcoma and plazmocito$\mathrm{ma}$. This condition dictates thorough diagnostic evaluation including CT and MRI scans with mandatory palatal lesion biopsy. This case presents 80 year old patients with solitary kidney adenocarcinoma metastasis on the medial part of the hard palate originating from light cell kidney carcinoma with already documented relapse.

\section{O24 PRIMARY EXTRANODULAR ORAL CAVITY NHL}

Kristijan Novački ${ }^{1}$, Tihomir Kuna ${ }^{2}$, Irina Filipović Zore ${ }^{3}$, Dragana Gabrić Pandurić ${ }^{3}$

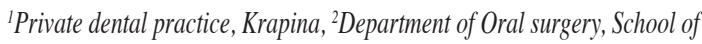
Dental Medicine, University of Zagreb, University Hospital Centre Zagreb

Non-Hodgkin lymphomas (NHL) are heterogeneous group of lymph proliferative neoplasms that are recognized by malignantly changed lymphocytes in lymph nodes, and rarely in other organs. Malignant lymphomas are rare in oral cavity and account for $3.5 \%$ of all malignant changes in oral region. We presented two patients with primary extra nodular oral cavity NHL. First patient had primary NHL on gingiva, the other had NHL in post extraction alveoli that did not heal. Based on the histological and immunohistochemical results, the diagnosis was diffuse large cell B-immunophenotype lymphoma. After combining radiotherapy with chemotherapy, both patients experienced complete disease withdrawal without any clinical signs. Diagnosing the extra nodular lymphoma presents a challenge because almost always there is a doubt that it might be a malignant neoplasm that if often concealed with oral and dental pathological conditions. Early diagnosis of malignant lymphoma of oral cavity is proportional to treatment success.

\section{O25 INTRAORAL ADENOID CYSTIC CARCINOMA: DOES THE} PRESENCE OF PERINEURAL INVASION CORRELATE WITH THE SIZE OF THE PRIMARY TUMOR, LOCAL INVASION, SURGICAL BORDERS, DISTANT METASTASES AND THE OUTCOME OF TREATMENT

Kristijan Dinjar ${ }^{1}$, Ivica Lukšíc ${ }^{2}$

${ }^{I}$ Department of Maxillofacial Surgery, University Hospital Center Osijek,

${ }^{2}$ Department of Maxillofacial and Oral Surgery, University Hospital Dubrava, School of Medicine, University of Zagreb

Adenoid cystic carcinoma or cylindroma is the most common malignant tumor of small salivary glands. It is characterized by slow growth, perineural spread of disease, the hematogenous transplants, which are three times more common than lymphogenous ones, distant transplants without regional spread of disease and lifelong monitoring of the patient. The aim of this research was to examine the connection between perineural spread of disease and the size of the tumor itself, local spread of disease, positive surgical borders, distant transplants and the outcome of treatment of patients with the intraoral cylindroma of small salivary glands. The research was conducted on a total of 44 patients of the 
ma iz literature sa kojima se u nekim segmentima nisu usuglasili. Intraoralni cilindrom se javlja tijekom petog i šestog desetljeća života, malo češće u ženskog spola. Lokalno širenje bolesti i specifična stopa preživljenja bolesti su u značajnoj povezanosti sa perineuralnim širenjem, dok veličina početnog tumor, pozitivni kirurški rubovi i udaljene presadnice nisu pokazale nikakvu povezanosti s perineuralnim širenjem bolesti.

\section{O26 NEPREPOZNAVANJE I KRIVO LIJEČENJE KARCINOMA USNE} ŠUPLINE I OROFARINKSA

Branko Janković1 ${ }^{\text {, Vjeran Bogović }}$, Vedran Zubčić ${ }^{1}$, Željko Zubčić ${ }^{3}$, Dinko Leović $^{1}$

${ }^{\prime}$ Odjel za maksilofacijalnu kirurgiju, KBC Osijek, ${ }^{2}$ Medicinski fakultet

Osijek, Sveučilište Josipa Jurja Strossmayera u Osijeku, ${ }^{3}$ Klinika za

otorinolaringologiju i kirurgiju glave i vrata, KBC Osijek

Cilj ove studije bio je analizirati neprepoznavanje tumorske bolesti u ustima i orofarinksu od strane liječnika opće prakse i stomatologa. Dostatni anamnestički podatci nađeni su za 256 bolesnika od kojih je 168 (65,6\%) imalo karcinom usne šupljine, a 88 (34,4\%) karcinom orofarinksa. Ukupna stopa neprepoznavanja i pogrešnog liječenja iznosi $46 \%$ (118 bolesnika), dok je kod 138 bolesnika (54\%) bolest odmah prepoznata. Stopa neprepoznavanja karcinoma usne šupljine; 75/168 (45\%) i orofarinksa; $43 / 88$ (49\%) podjednaka je. Najviša stopa neprepoznavanje bolesti nađena je kod doktora dentalne medicine; 30 bolesnika od 51 pregledanih $(58,8 \%)$. Doktori opće prakse bolest nisu prepoznali u 42,4\% slučajeva; 84 bolesnika od 198 pregledanih. U sedam bolesnika pregledanih od ostalih specijalnosti stopa neprepoznavanja i pogrešnog liječenja iznosi $57,1 \%$, odnosno četiri bolesnika od sedam pregledanih. Autori zakljucuju da je stopa neprepoznavanja i pogrešnog liječenja oralnog i orofaringealnog karcinoma u Republici Hrvatskoj i dalje vrlo visoka. Naročito je zabrinjavajuća visoka stopa neprepoznavanja oralnog karcinoma, dostupnog inspekciji (45\%). Ovi podatci govore i da je potrebno posvetiti veću pozornost klinickoj slici intraoralnog karcinoma tijekom preddiplomske nastave, posebice kod studenata dentalne medicine.

\section{IZOLIRANI RECIDIV VRATA: NJEGOV PROGNOSTIČKI ZNAČAJ I POVEZANOST S TIPOM DISEKCIJE \\ Ivan Mumlek ${ }^{1}$, Ivan Sabol' ${ }^{2}$, Vedran Zubčić ${ }^{1}$, Dinko Leović ${ }^{1}$ \\ ${ }^{\prime}$ Odjel za maksilofacijalnu kirurgiju, KBC Osijek, ${ }^{2}$ Zavod za molekularnu medicinu Instituta „Ruđer Boškovic“", Zagreb}

Cilj ove studije je utvrditi učestalost izoliranog recidiva u vratu i njegov prognostički značaj. U tu svrhu analizirani su samo s p $\mathrm{N}+$ disektati, isključeni su svi bolesnici s drugim primarnim tumorom/tumorima, kao i oni s lokalnim recidivom. Bolesnici su praćeni minimalno dvije godine. Kriterije uključenja zadovoljilo je 68 bolesnika u kojih su učinjene 73 disekcije uz kasniji pozitivni patohistološki nalaz vrata. pN status disektata bio je sljedeći: N1: 21 (28,8\%), N2a: 3 (4,1\%), N2b: 41 (56,2\%), N2c: 1 (1,4\%), N3: 7 (9,5\%). Izolirani recidiv u vratu nađen u 4 od 73 disekcije $(5,5 \%)$. U sva četiri slučaja $\mathrm{pN}$ status vrata bio je $2 \mathrm{~b}$, a u dva slučaja bio je prisutan proboj čahure čvora. Kod dvoje bolesnika učinjena je radikalna disekcija vrata. Stopa izoliranog recidiva u vratu nakon radikalne disekcije kod pN2b (n=41) tako iznosi 9,1\% budući da je izolirani recidiv naden nakon dvije disekcije od 22 učinjene. Nakon ostalih disekcija kod pN2b nalaza stopa recidiva je sljedeća: modificirana radikalna disekcija uz čuvanje jugularne vene - 1/6 (16,7\%), selektivna anerolateralna disekcija- $1 / 7$ (14,3\%). Autori unatoč malom broju analiziranih bolesnika zaključuju da čuvanje jugularne vene vjerojatno ima utjecaj na pojavu izoliranog recidiva u operiranom vratu kod višh $\mathrm{pN}$ stupnjeva. Utjecaj izoliranog regionalnog recidiva na preživljenje nije od primarnog značaja budući da njegova ukupna stopa iznosi 5,5\%.S druge strane kod 24 bolesnika od 68 analiziranih $(35,3 \%)$ razvile su se udaljene metastaze koje su glavni uzrok mortaliteta u bolesnika kod kojih se nije razvio lokalni recidiv.

\section{O28 ZRAČENJEM INDUCIRANI TUMORI GLAVE I VRATA}

Igor Blivajs, Mišo Virag

Klinika za kirurgiju lica, čeljusti i usta, KB Dubrava, Medicinski fakultet, Sveučilište u Zagrebu

Zračenjem inducirani tumori glave i vrata vrlo su rijetki tumori, nejasno definirani radi nepostojanja jasnog biološkog markera. Smatraju se jatrogenim tumorima, odnosno tumorima nastalim kao posljedica ranijeg radioterapijskog liječenja. Aktualna saznanja o navedenoj problematici plod su istraživanja tumora nastalih u populaciji pacijenata izloženih visokim dozama zračana kao što su preživjeli iz velikih nukleranih kastastrofa (Hiroshima i Nagasaki, Černobil). Također je poznat visok rizik nastanka zračenjem induciranih tumora u populaciji pacijenata koji boluju od predisponirajućih sindroma (neurofibromatoza, fibrozna displazija). Uvidom u medicinsku dokumentaciju naše Kli-
Clinic for Face, Jaw and Mouth Surgery of the Clinical Hospital Dubrava between 1984 and 2008, which have all been diagnosed with intraoral cylindroma of small salivary glands. The obtained results have been compared to the results given in literature, which have shown discrepancies in certain segments. Intraoral cylindroma usually occurs during the fifth and the sixth decade of life, more frequently in women. The local spread of disease and the specific survival rate are in a considerable correlation with the perineural spread, while the size of the initial tumor, positive surgical borders and distant transplants have not shown any correlation with the perineural spread of the disease.

\section{O26 UNRECOGNISED AND MISTREATED ORAL CAVITY AND} OROPHARYNKS CARCINOMA

Branko Janković1 ${ }^{1}$ Vjeran Bogović ${ }^{2}$, Vedran Zubčić1 ${ }^{1}$ Željko Zubčicí ${ }^{3}$, Dinko Leović ${ }^{1,2}$

${ }^{1}$ Department of Maxillofacial Surgery, ${ }^{2}$ School of Medicine, University "Josip

Juraj Strossmayer", Osijek, ${ }^{3}$ Department of Otorhinolaryngology, Head and

Neck Surgery, ${ }^{1,3}$ University Hospital Center Osijek

The purpose of this study was to analyze the cases of unrecognized tumors in oral cavity and oropharynx by general physicians and dentists. Health records were obtained for 256 patients from which $168(65 . \%)$ had oral cavity carcinoma and $88(34,4 \%)$ had oropharynx carcinoma. The rate at which physicians and dentists did not recognize or mistreated is $46 \%$ (118 patients) whereas in 138 patients (54\%) the disease was recognized immediately. The rates at which oral carcinoma and oropharynx carcinoma were unrecognized were similar, 75/168 (45\%) and 43/88 (49\%) respectively. The highest rate of unrecognized disease was in found with dentists; 30 patients out of 51 screened (58.5\%). General physicians did not recognize the disease with the rate of 42.4\%; 84 patients out of 198 screened. Authors conclude that the rate at which oral carcinoma and carcinoma of the oropharynx pass unrecognized is very high in the Republic of Croatia. It is particularly concerning the fact that oral carcinoma goes unrecognized at the rate of $45 \%$ when it is available for direct inspection. This data shows that it is very important to dedicate more academic time during undergraduate education in order for students to have better understanding of the clinical aspects of oral carcinoma and carcinoma of the oropharynx.

\section{ISOLATED NECK RELAPSE: PROGNOSTIC MEANING AND CONNECTION WITH THE TYPE OF DISSECTION \\ Ivan Mumlek ${ }^{1}$, Ivan Sabol ${ }^{2}$, Vedran Zubčić1 ${ }^{1}$, Dinko Leović \\ ${ }^{\prime}$ Department of Maxillofacial Surgery, University Hospital Center Osijek, \\ 2Department of Molecular Medicine, Institute „Ruđer Boškovic“", Zagreb}

The purpose of this study was to establish the frequency of isolated neck relapse and the prognostic meaning behind it. For this purpose we analyzed only $\mathrm{pN}+$ dissected tissue. All the patients with other primary tumors, as well as the patients with local relapse, were excluded from the study. The chosen subjects were then followed for two years. Inclusion criteria were satisfied by 68 patients on whom 73 dissections were made followed by positive PHD results. pN status of the dissected tissue is as follows: N1: 21 (28,8\%), N2a: 3 (4,1\%), N2b: 41 (56,2\%), N2c: 1 (1,4\%), N3: 7 (9,5\%). Isolated neck relapse emerged in 4 out of 73 dissections (5.5\%). In all 4 cases $\mathrm{pN}$ status was $2 \mathrm{~b}$ and in two cases the breach of node follicle was observed. Two patients needed a radical neck dissection. The rate of isolated neck relapse after radical dissection with $\mathrm{pN} 2 \mathrm{~b}(\mathrm{n}=41)$ is $9.1 \%$ since only 2 cases were noticed after 22 dissections were done. After other resections with $\mathrm{pN} 2 \mathrm{~b}$ results, the relapse rate is as follows: modified radical neck dissection with jugular preservation - 1/6 (16.7\%), selective anterior lateral dissection - 1/7 (14.3\%). Authors conclude that despite the small sample size, jugular preservation has an influence on recurrence of isolated neck relapse with higher $\mathrm{pN}$ degrees. The impact of isolated regional relapse on survival rate is not a substantial one since its combined rate is $5.5 \%$. On the other hand, 24 out of 68 patients developed metastasis on other organs and tissues. A scenario that leads to increased mortality rate in patients with regional neck relapse.

\section{O28 RADIATION INDUCED HEAD AND NECK TUMOR}

Igor Blivajs, Mišo Virag

University Hospital Dubrava, Department of Maxillofacial and Oral Surgery, School of Medicine, University of Zagreb, Croatia

Radiation induced head and neck tumors are rare tumors, not defined clearly due to the lack of clear biological marker. They are considered to be induced by earlier radiation that was a part of therapy. Recent findings on these tumors are results of log term research efforts conducted on the survivors from large scale nuclear disasters (Hiroshima i Nagasaki, Černobil). Population of patients who have predisposing syndromes like neurofibromatosis or fibrous dysplasia also have a high risk of developing a radiation induced tumors. By looking through our clinic's medical files we selected 9 patients with high risk of developing radiation induced tumors. We also presented radiation tumor diagnosis, in- 
nike selektrirali smo 9 pacijetna sa visokom vjerojatnošću induciranog tumora te prikazali dijagnoze induciranog tumora, pojedinačno i prosječno preživljenje, vremenski raspon izmedu prvog i induciranog tumora te krajnji ishod bolesti. Dobiveni rezultati u skladu su s literaturom. Obzirom da radioterapija ostaje bitan modalitet liječenja onkoloških pacijenata, potrebna je svijest o induciranim tumorima, posebice nakon dugog razdoblja latencije od ranijeg liječenja.

Ključne riječi: Tumori glave i vrata, radioterapija, inducirani tumori.

\section{O29 METASTAZA KARCINOMA PLUĆA OPONAŠA ODONTOGENU UPALU}

Mate Miloš, Spomenka Manojlović, Dalibor Franćeski, Karmen Trutin Ostović, Darko Macan

KB Dubrava, Stomatološki fakultet, Medicinski fakultet, Sveučilište u Zagrebu

Metastaze malignih tumora u usnu šupljinu su daleko rjede od primarnih lezija. Učestalost malignih neoplazmi:metastaza u usnoj šupljini je 3-5\%:1\%. Gornja i donja čeljust se rutinski ne pregledavaju pri obdukciji pa prava učestalost može biti veća. Metastaze u gingivu ili u ostala meka tkiva javljaju se u oko $0.1 \%$ slučajeva. Metastaze mogu zahvatiti zajedno tvrda i meka tkiva te jezik. Sve ove lezije mogu utjecati iznimno štetno na oralnu funkciju, govor i prehranu. Adekvatno liječenje i lokalna kontrola poboljšavaju prehrambeni status i kvalitetu života. Metastatski tumori nalaze se češce u mandibuli nego u maksili i to češće u premolarnoj i molarnoj regiji. Zajednička primarna sijela tumora koji najčesće metastaziraju u usnu šupljinu su grudi, pluća, debelo crijevo i bubreg. Pluća su najčešće sijelo tumora koji metastazira u usnu šupljinu. Mandibula je najčešća lokacija metastaza gdje je molarna regija najviše zastupljena. Dijagnoza može biti komplicirana čestim nedostatkom dovoljno karakterističnih značajki koje izdvajaju ovakve lezije klinički i radiološki od ostalih benignih lezija endodontskog porijekla i ostalih upalnih bolesti. Kliničar bi trebao prepoznati mogućnost metastaze, a patolog sijelo primarnog tumora. U opisanim prikazima slučajeva u literaturi često je postavljena pogrešna dijagnoza, pogotovo u ranim stadijima bolesti. Prikazujemo bolesnika s metastazom pluća u alveolarni greben maksile što je krivo dijagnosticirano kao periapeksna odontogena upala.

\section{O30 EPIDEMIOLOŠKE I KLINIČKE KARAKTERISTIKE POJEDINIH PRIJELOMA DONJE ČELJUSTI \\ Marijan Dobranić, Igor Čvrljević, Naranđa Aljinović Ratković \\ Klinika za kirurgiju lica, č ljusti i usta, KB Dubrava, Medicinski fakultet, Sveučilište u Zagrebu}

Područje lica je jedno od najčešće ozljedenih područja tijela, a mandibula je njačěšce prelomljena kost (36-54\%) na glavi. Frakture mandibule podijeljene su prema mnogim klasifikacijama i dijagnosticirane su od strane kliničara i radiologa. Cilj ovog istraživanja je prikazati etiologiju i učestalost fraktura mandibule u Hrvatskoj u periodu od 5 godina. Podaci (klinički dokumenti, medicinska dokumentacija) su skupljeni i analizirani. Parametri su bili spol, dob, etiologija i mjesto frakture. Proveli smo retrospektivno istraživanje svih mandibularnih fraktura od 1.1.2004. do 31.12.2010. godine. U periodu od pet godina liječeno je 379 pacijenata. Omjer muških pacijenata naspram ženskih bio je 4:1. Najvažniji etiološki faktor bilo je mađusobno nasilje, nesreće u prometu i padovi. Najčesće mjesto frakture je kondil (30\%) angulus (26\%), simfiza (23\%) i tijelo mandibule (19\%) uz pojavu sporadičnih fraktura na ostalim mjestima. Rezultati su pokazali da je kod muškaraca kao urok frakture prevladavalo nasilje dok su kod žena to bili padovi. Uzimajući dob u obzir, najvažniji etiološki čimbenici su prometne nezgode u mlađoj populaciji, nasilje kod adolescenata, mladih ljudi i starije populacije te padovi u starijoj populaciji. Isto tako smo istražili mjesta frakture i usporedili ih sa spolom, etiologijom i dobi pacijenata.

Ključne riječi: mandibula, frakture, etiološki čimbenici

\section{O31 PROCJENA UČINKOVITOSTI DIODNOG LASERA NA KVALITETU ŽIVOTA NAKON KIRURŠKOG UKLANJANJA TREĆIH DONJIH MOLARA}

Goran Batinjan ${ }^{1}$, Ivana Rupić, Irina Filipović Zore ${ }^{1,2}$, Dragana Gabrić Pandurić 'Zavod za oralnu kirurgiju, Stomatološki fakultet, Sveučilište u Zagrebu, ${ }^{2}$ Klinika za stomatologiju, KBC Zagreb

Cilj ovoga rada bio je ispitati učinkovitost laserskog zračenja u redukciji postoperativne primjena analgetika, smanjenju broja dana radne nesposobnosti, te procijeniti kvalitetu života bolesnika nakon operativnog zahvata ovisno o načinu tretiranja laserom. Uzorak se sastojao od 150 pacijenata s apsolutnom indikacijom za kirurško uklanjanje donjeg umnjaka. U istraživanju se koristio Laser HF. Ispitanici su slučajnim odabirom podijeljeni u tri skupine: prva skupina sastojala se od 50 pacijenata koji su primili aPDT terapiju, drugu skupinu su činili 50 pacijenata koji su primili LLLT terapiju, dok su preostalih 50 dividual and average survival rate, time span between initial tumor and induced tumor, and the final end result. Our results mirror the ones found in literature. Due to the fact that radiotherapy remains an important treatment modality for tumor patients, therapists should be more conscious about induced tumors especially if there has been a long latency period from the last treetment.

Key words: head and neck tumors, radiotherapy, induced tumors

\section{O29 LUNG CARCINOMA MIMICKING ODONTOGENIC INFECTION}

Mate Miloš, Spomenka Manojlović, Dalibor Franćeski, Karmen Trutin Ostović, Darko Macan

University Hospital Dubrava, School of Dental Medicine, School of Medicine, University of Zagreb

Malignant tumor metastasis to oral cavity is a rare occurrence, far less common than primary lesions. The ratio of malignant neoplasms vs. metastasis in oral cavity is around 3-5\%:1\%. Upper and lower jaws are not screened for tumors during autopsy making it possible for the occurrence of metastasis to be even larger. Gingival and soft tissue metastases are present in around $1 \%$ of all the cases. Metastasis can be present in both soft and hard tissue including the tongue. All the pre mentioned lesions have very negative influence on oral functions, speech and nutrition. Adequate treatment and local control improve nutritional status and quality of life. Metastatic tumors are found more often in mandible than in maxilla. More precise mandibular location is in premolar and molar region. Common primary tumor locations that metastasize to oral cavity are breast, lungs, colon and kidneys. Of the pre mentioned, lung tumors metastasize more often than other tumors. They can be hard to diagnose due to the lack of characteristic features of such lesions that would separate them from other benign lesions with endodontic origin or other inflammatory conditions. Clinician should be able to recognize the possibility of metastasis, and the pathologist should be able to recognize the primary tumor location. We found that in case reports from the literature clinicians often misdiagnosed the case, especially in the early stages of the disease. In our case report we present a patient with lung cancer metastasis to alveolar ridge of the upper jaw being wrongly diagnosed as a periapical odontogenic inflammation.

\section{EPIDEMIOLOGIC AND CLINICAL CHARACTERISTICS OF CERTAIN} MANDIBULAR FRACTURES

Marijan Dobranić, Igor Čvrljević, Naranđa Aljinović Ratković

University Hospital Dubrava, Department of Maxillofacial and Oral Surgery, School of Medicine, University of Zagreb, Croatia

The facial area is one of the most common injured areas of the body and the mandible is one of the most frequently fractured bones (36-54\%) in the craniomaxillofacial area. Mandibular fractures are divided by many different classifications and are diagnosed by clinical and radiological examination. The aim of this study is to show etiology and frequency of mandibular fractures in Croatia over a period of 5 years. Data (clinical records, patient's files) was reviewed and analyzed in terms of gender, age, etiology and anatomical localization. We conducted a retrospective study of all mandibular fractures treated from January $1^{\text {th }}, 2004$ to December $31^{\text {th }}, 2010$. In a period of 5 years 379 patients were treated, with male to female ratio 4:1. The most important etiological factor was interpersonal violence, followed by traffic accidents and falls. The most common fracture sites were condyl (30\%), angulus (26\%), symphisis (23\%) and corpus (19\%), with other localizations appearing sporadically. Our results show the predominance of interpersonal violence in men and falls in females as a main etiological factor. Considering age, traffic accidents in young population, interpersonal violence in teenager, young adult and mature population and falls in older population are the most important etiological factors. We also determined other localization specific correlations between age, gender and etiology. Key words: mandible bone, fracture, etiological factor

\section{O31 EVALUATING THE EFFECTIVENESS OF THE DIODE LASER ON THE QUALITY OF LIFE AFTER SURGICAL REMOVAL OF LOWER THIRD MOLARS}

Goran Batinjan ${ }^{1}$, Ivana Rupić, Irina Filipović Zore ${ }^{1,2}$, Dragana Gabrić Pandurić ${ }^{1}$ ${ }^{l}$ Department of Oral Surgery, School of Dental Medicine, University of Zagreb, ${ }^{2}$ Department of Stomatology, University Hospital Centre Zagreb

The purpose of this study was to evaluate the effectiveness of the laser irradiation on the reduction of postoperative analgesic consumption, reducing the number of days of incapacity, and to assess the quality of life of patients after the surgical removal of third lower molars, depending on the laser treatment. The research consisted of 150 patients with the absolute indications for removal of lower third molars. The laser, Laser HF was used in the research. Patients were randomly divided into three groups, 50 per each group. The first group received aPDT, second group LLLT and the third was indicated as the con- 
pacijenata bili kontrolna skupina. Svim pacijentima uručene su identične postoperativne upute. Postoperativni posjeti bili su zakazani na treći i sedmi dan kada se, kod ispitanika koji su primili lasersku terapiju, provodio tretman rane istim postupcima koji su se provodili i na dan operativnog zahvata. Korištena su 2 upitnika, jedan koji su ispunjavali pacijenti i jedan koji je ispunjavao terapeut te upitnik o zadovoljstvu pacijenta OHIP - CRO14 (Oral Health Impact Profile). Prosječna ocjena poteškoća u hranjenju, spavanju i govoru eksponencijalno se smanjivala kroz 14 dana postoperativnog praćenja u sve 3 skupine pacijenata, ali je pad najviše bio izražen kod ispitanika skupine aPDT. Može se zaključiti da aPDT najbolje reducira postoperativne tegobe, te su njeni ispitanici postoperativno bili zadovoljniji od ispitanika LLLT i kontrolne skupine. Pacijentova dob, spol i navike nisu bile statistički značajno povezane s postoperativnim oporavkom. Laserska terapija statistički značajno $(\mathrm{p}<0.001)$ smanjuje mogućnost nastanka postoperativnih komplikacija cijeljenja, reducira upotrebu analgetika te smanjuje broj dana radne nesposobnosti. Oba korišstena modaliteta laserske terapije statistički značajno $(\mathrm{p}<0.001)$ reduciraju postoperativne tegobe.

\section{O32 ORALNO KIRURŠKI ZAHVATI KOD PACIJENATA NA ANTIKOAGULANTNOJ I ANTITROMBOCITNOJ TERAPIJI \\ Tomislav Ćabov ${ }^{1}$, Berislav Perić ${ }^{2}$}

${ }^{\prime}$ Klinika za maksilofacijalnu i oralnu kirurgiju, Studij dentalne medicine, Medicinski fakultet, Sveučilište u Rijeci, ${ }^{2}$ Klinika za kirurgiju lica, čeljusti $i$ usta, Klinički zavod za oralnu kirurgiju, KB Dubrava, Stomatološki fakultet, Sveučilište u Zagrebu

Antikoagulantni i antitrombocitni lijekovi predstavljaju skupinu lijekova u terapiji i prevenciji tromboembolijskih bolesti. Povećani broj indikacija za terapijom antitrombocitnim i antikoagulantnim lijekovima stavlja doktore dentalne medicine u položaj da su svakodnevno u svom radu u prilici pružati dentalnu terapiju takvim pacijentima. Svrha ovoga rada je prikazati različite antikoagulantne i antitrombocitne lijekove, njihov mehanizam djelovanja, učinak na postoperativno krvarenje, te ukazati na smjernice za svakodnevni dentalni rad i oralno-kirurške zahvate kod pacijenata na antikoagulantnoj i antitrombocitnoj terapiji.

\section{ZAŠTO SVAKI DOKTOR TREBA ZNATI O BIFOSFONATIMA}

Davor Brajdić, Darko Macan

Klinika za kirurgiju lica, čljusti i usta, Klinički zavod za oralnu kirurgiju, KB

Dubrava, Stomatološki fakultet, Sveučilište u Zagrebu

Bifosfonati se već tri desetljeća kao poznata skupina lijekova u kliničkoj uporabi koriste za liječenje stanja povezanih s malignim bolestima. To su maligna hiperkalcijemija i koštane metastaze povezane s karcinomima, kao što su karcinom dojke u žena, karcinom prostate, karcinom pluća i litičke lezije kod multiplih mijeloma. Oralni bifosfonati odobreni su za liječenje osteoporoze i osteopenije. Također se koriste kod Pagetove bolesti i osteogenesis imperfekta u djetinjstvu. Unatoč brojnim nuspojavama, prema posljednjim istraživanjima ta skupina lijekova sve više obećava u smislu proširenja terapijskih indikacija. Njihova učinkovitost je ispitana i u liječenju pacijenata koji boluju od fibrozne displazije, u području maksilofacijalne i oralne kirurgije mogu se upotrijebiti prilikom distrakcijske osteogeneze, transplantacije kosti, dentalne implantologije, tj. tamo gdje je potrebito stvaranje i očuvanje novostvorene kosti. Činjenica je da se uvidom u stručnu i znanstvenu literaturu unatrag nekoliko godina sve više spominje osteonekroza čljusti u pacijenata koji su pod terapijom bifosfonatima (BRON-Bisphosphonate-related osteonecrosis of the jaw), osobito nakon ekstrakcije zuba, a o tome se kod nas relativno malo piše i zna. Prvi je puta spomenuta u British Medical Journal 1899. godine, kao promjena na čeljusnim kostima oboljelih radnika u rudnicima fosfora u Velikoj Britaniji. Godine 2003. oralni maksilofacijalni kirurzi u svijetu su prepoznali i prvi put izvijestili o slučajevima nezarastajućih otvorenih koštanih lezija u maksilofacijalnoj regiji u pacijenata liječenih parenteralnim preparatima bifosfonata. Prema literturi, incidencija osteonekroze čeljusti izazvane bifosfonatima (BRON-a) kreće se od 0,8\%-12\%. Rizik za razvoj komplikacija u obliku nastanka avaskularne nekroze sluznice, osteonekroze, osteomijelitisa ili osteoradionekroze je veći kod potentnijih bifosfonata koji se ordiniraju parenteralno, kao što je Aredia (pamidronat - dinatrij) i Zometa (zoledronat), a manji kod peroralnih preparata kao što su Pleostat (etidronat - dinatrij), Fosamax (alendronat - natrii), Actonel (risedronate) i Bonefos (klodronat - dinatrij). Budući da spomenute promjene na čeljusti najčešce počinju kao parodontna bolest ili ulkus koji ne cijeli, za stomatologa praktičara najvažniju ulogu ima prevencija u smislu ranog prepoznavanja i održavanja oralnoga zdravlja minimalno invazivnim postupcima u bolesnika koji su pod terapijom bifosfonatima. trol group. All patients received identical postoperative instructions. Postoperative visits were scheduled on the third and seventh day when the patients from laser groups, were treated following the same protocol on the day of the surgery. Healing and postoperative recovery was assessed by two questionnaires, one for patients and another for surgeons, and OHIP - CRO14 (Oral Health Impact Profile). Average grades for feeding problems, sleeping problems, and talking problems decreased exponentially during the 14 days of postoperative monitoring in all three groups, but the highest average grade drop was in the aPDT group. It can be concluded that the group with the lowest postoperative discomfort was the aPDT group, and patients in the aPDT group were more satisfied than the patients in the LLLT and control groups. Age, gender, habits and preoperative medicine usage do not influence postoperative recovery. The laser therapy statistically significantly $(\mathrm{p}<0.001)$ reduced postoperative complications of healing, use of analgesics and the number of days of incapacity. Both modalities of laser therapy statistically significantly $(\mathrm{p}<0.001)$ reduced postoperative problems.

\section{ORAL SURGERY PROCEDURES IN PATIENTS USING ANTICOAGULANT AND ATIPLATELET MEDICATIONS Tomislav Ćabov ${ }^{1}$, Berislav Perić ${ }^{2}$}

${ }^{l}$ Department of Maxillofacial and Oral Surgery, Dentistry Study, School of Medicine, University of Rijeka, ${ }^{2}$ Department of Maxillofacial and Oral Surgery, University Hospital Dubrava, School of Dental Medicine, University of Zagreb

Anticoagulant and antiplatelet medications represent the group of drugs in the treatment and prevention of thromboembolic diseases. The expanding indications for anticoagulant and antiplatelet drugs in the last decade have lead the dentists, oral and maxillofacial surgeons to provide daily dental treatment or oral surgery to such patients. The purpose of this article is to review the various anticoagulant and antiplatelet drugs, their mode of action, their effect on postoperative bleeding, and to point out the daily dental treatment and oral surgery procedures on patients under anticoagulant or antiplatelet therapy.

\section{WHY EVERY DOCTOR SHOULD KNOW ABOUT BISPHOSPHONATES \\ Davor Brajdić, Darko Macan \\ Department of Maxillofacial and Oral Surgery, University Hospital Dubrava, School of Dental Medicine, Universitiy of Zagreb}

Bisphosphonates are known group of drugs in clinical use already for three decades and used to treat conditions associated with malignant diseases. These are malignant hypercalcaemia, bone metastases associated with cancers such as breast cancer in women, prostate cancer, lung cancer and lytic lesions in multiple myeloma. Oral bisphosphonates have been approved for the treatment of osteoporosis and osteopenia. It is also used for Paget's disease and osteogenesis imperfecta in childhood. Despite numerous side effects, according to recent studies these drugs are more promising in terms of their therapeutic indications. Their effect was tested in the treatment of patients with fibrous dysplasia and can be used during distraction osteogenesis, bone transplantation, dental implants, or where it is necessary to create and preserve the newly formed bone. The fact is that by examining the scientific literature over the last few years more and more mentioned osteonecrosis of the jaw in patients treated with bisphosphonates (BRON-Bisphosphonate-related osteonecrosis of the jaw), especially after tooth extractions that in our relatively small writes and knows. It was first mentioned in the British Medical Journal in 1899 as changes in the jaw bone affected workers in the mines of phosphorus in the UK. In 2003 oral and maxillofacial surgeons in the world have recognized and reported cases of open bone lesions in the maxillofacial region in patients treated with intravenous bisphosphonates. In the literature, incidence of osteonecrosis of the jaw caused by bisphosphonates (BRON-a) ranges from $0.8 \%-12 \%$. The risk of developing complications such as a vascular necrosis, osteonecrosis, osteomyelitis or osteoradionecrosis is related to more potent parenteral bisphosphonates as Aredia (pamidronate - disodium) and Zometa (zoledronate), and lower risk is with peroral preparations such as Pleostat (etidronate - disodium), Fosamax (alendronate - sodium), Actonel (Risedronate) and Bonefos (chlodronate - disodium). Since these changes in the jaw usually begin as periodontal disease or ulcer that does not heal, the dental practitioner has the most important role in terms of prevention and early recognition and maintenance of oral health by minimally invasive procedures in patients treated with bisphosphonates. 
034 HIPOKLORIT - BEZAZLENA OTOPINA ZA ISPIRANJE KORIJENSKIH KANALA?

Petar Đanić1 ${ }^{1}$, Dalibor Frančeski², Darko Macan ${ }^{1}$

${ }^{\prime}$ Klinika za kirurgiju lica, čeljusti i usta, Klinički zavod za oralnu kirurgiju,

KB Dubrava, Stomatološki fakultet, Sveučilište u Zagrebu, ${ }^{2}$ Klinički zavod za dijagnostičku i intervencijsku radiologiju, KB Dubrava, Zagreb

Uspješnost endodontske terapije temelji se ne samo na mehaničkoj instrumentaciji već i na kemijskoj obradi endodontskog prostora. Danas kako u svijetu tako i kod nas najčešce korištena otopina za ispiranje korijenskih kanala je natrijev hipokorit. Uz brojna dobra fizikalno-kemijska svojstva, važno je istaknuti negativno i potencijalno opasno svojstvo natrijevog hipoklorita, a to je citotoksičnost. Brojna istraživanja pokazala su da je natrijev hipoklorit citotoksičan na sve stanice osim na stanice keratiniziranog epitela, te da citotoksičnost i njezine posljedici ovise o koncentraciji, količini, vremenu ekspozicije i pH otopine. Prikazujemo slučaj pacijentice sa trajnim posljedicama incidenta uzrokovanim uporabom natrijeva hipoklorita tokom endodontskog liječenja. U prikazu osvrnut ćemo se i na mogućnosti prevencije, te liječenja neželjenih posljedica citotoksičnog djelovanja natrijeva hipoklorita.

\section{ARTROSKOPIJA TEMPOROMANDIBULARNOG ZGLOBA \\ Margita Belušić-Gobić}

Klinika za maksilofacijalnu i oralnu kirurgiju, KBC Rijeka, Medicinski fakultet, Sveučilište u Rijeci

Temporomandibularna disfunkcija ili poremećaj (TMD/TMP) je zajednički naziv koji se koristi za brojna bolna stanja čeljusti (orofacijalne boli) koja isključuju odontogeno porijeklo boli. Cilj dijagnostičkog postupka je utvrditi da li se radi o poremećaju na nivou žvačnih mišića (miogena disfunkcija) ili na nivou samog temporomandibularnog zgloba (artrogena disfunkcija). Pacijent može imati u isto vrijeme i mišićnu i artrogenu disfunkciju, što otežava postavljanja prave dijagnoze i izbor liječenja. Miogena disfunkcija je češća i uglavnom se liječi konzervativno. Postoje brojne nekirurške metode liječenja temporomandibularnog poremećaja i one su uvijek prvi izbor u liječenju. Opće prihvaćena konzervativna terapija ubuhvaća bihevioralnu terapiju, fizikalnu terapiju, farmakološku terapiju i upotrebu okluzalnih splintova. U radu se prikazane mogućnosti pojedine vrste liječenja, njezini dosezi, ograničenja, prednosti i nedostaci. Artrocenteza i artroskopija spadaju u mikroinvazivne kirurške metode liječenja temporomandibularnog poremećaja. Indikacije za artroskopiju su unutrašnji poremećaj zgloba (prvenstveno dislokacija diska sa redukcijom ili bez nje), adhezije, fibroza i degenerativne bolesti zgloba.Artroskopija temporomandibularnog zgloba u komparaciji s otvorenom kirurgijom zgloba, zbog svoje malene invazivnosti, izaziva manji kirurški morbiditet, ima manje komplikacija, dobro se podnosi. Predstavlja sigurni kirurški postupak sa dobrim rezultatima.

\section{PROTETSKO ZBRINJAVANJE NAKON VELIKIH REKONSTRUKCIJA ČELJUSTI}

\section{Zoran Kovač}

Klinika za dentalnu medicinu, KBC Rijeka, Studij dentalne medicine, Medicinski fakultet, Sveučiliš̌te u Rijeci

Defekti u predjelu čeljusti koji onemogućavaju ili otežavaju protetsko zbrinjavanje, najčešće su posljedica trauma s posledičnim gubitkom koštanih i mekih tkiva. Isto tako, ovi defekti mogu nastati nakon teških koštanih infekcija ili, znatno češće nakon radikalnih operacija malignih ili benignih tumora. Isti etiološki uzroci mogu dovesti do stvaranja većih ožiljaka na mekim tkivima usne šupljine i vestibuluma, tako da onemogućavaju izradu korektnih protetskih nadoknada. U predavanju su prikazani neki od slučajeva protetskog zbrinjavanja te razna protetska rješenja izrađena nakon kirurških rekonstrukcija čeljusti i lica.

\section{REHABILITACIJA ESTETSKE ZONE IMPLANTATIMA. PROBLEMI IZAZOVI TERAPIJE \\ Damir Jelušić \\ Dentalna poliklinika, Opatija}

Rehabilitacija estetske zone implantatima veliki je klinički izazov za svakog terapeuta, bilo da se radi o kiruškim ili protetskim aspektima implanto-protetske terapije. Ključni faktor početka uspješne terapije svakako je pre-impalntološka analiza i dijagnostika. 3D CBCT snimke od velike su nam pomoći pri odabiru ispravne strategije terapije, prije svega zbog mogućnosti objektivne ocjene stanja kosti i vestibularnog koštanog zida, naročito u situacijama gdje se ocjenjuje mogućnost sigurne i predvidljive imedijatne implantacije. Stanje mekih tkiva, primjerice, visina i oblik marginalnog ruba gingive, širina pričvrsne sluznice te biotip mekih tkiva, važni su faktori u palniranju implanto-protetske terapije. Analizom spomenutih faktora dolazi se do optimalnog plana liječenja koje uključuje točan redosljed kirurških i protetskih postupaka. Prilikom implantacije treba se voditi nače-
034 HYPOCHLORITE - HARMLESS SOLUTION FOR ROOT CANALS IRRIGATION?

Petar Đanić1 ${ }^{1}$ Dalibor Frančeski², Darko Macan ${ }^{1}$

${ }^{\prime}$ Department of Maxillofacial and Oral Surgery, University Hospital Dubrava, School of Dental Medicine, University of Zagreb, ${ }^{2}$ Department of Diagnostic and Interventional Radiology, University Hospital Dubrava, Zagreb

Success of endodontic treatment is based not only on the mechanical instrumentation but also on use of irritants. Today, both worldwide and in our country, the most popular irrigating solution is sodium hypochlorite. With many good physical and chemical properties, it is important to stress the negative and potentially dangerous property of sodium hypochlorite, which is cytotoxicity. Numerous studies have shown that sodium hypochlorite is cytotoxic to all cells except the keratinized epithelial cells, and that the cytotoxicity and its effects depend on the concentration, volume, exposure time and $\mathrm{pH}$ of the solution. We present a case of a patient with permanent consequences of the incident caused by the use of sodium hypochlorite during endodontic treatment. In the presentation we will discuss opportunities for prevention and treatment of adverse consequences cytotoxic activities of sodium hypochlorite.

\section{O35 ARTHROSCOPY OF THE TEMPOROMANDIBULAR JOINT Margita Belušić-Gobić \\ Department of Maxillofacial and Oral Surgery, University Hospital Center \\ Rijeka, School of Medicine, University of Rijeka}

Temporomandibular disorders (TMD) are collective term including several clinical problems. The diagnostic procedure goal is to distinguish if the patient has disorders of the masticator and cervical musculature (myogenous TMD) or has joint-related dysfunction (arthrogenous TMD). The two types can be presented as the same time, making diagnosis and treatment more challenging. Myogenous TMD is more common and the treatment is always conservative. Non-surgical modalities are essential in the treatment of most joint dysfunctions and those are cognitive-behavioral therapy, medications, physical therapy, oclusal splints. The presentation includes comparison among different treatment modalities, their efficacy, advantages, disadvantages and limitation. TMJ arthrocentesis and arthroscopy are micro invasive surgical methods of treatment. Arthroscopic surgery has changed the therapeutic approach of functional disorders of the temporomandibular joint significantly. The indications for arthroscopic surgery include internal derangements, adhesions, fibrosis and degenerative joint diseases. Arthroscopic surgery causes less surgical morbidity and has less severe complications in comparison with open surgical procedure. It is save surgery end effective treatment method.

\section{O36 PROSTHETIC TREATMENT AFTER A MAJOR RECONSTRUCTION OF THE JAW}

Zoran Kovač

Department of dental medicine, University Hospital Center Rijeka, Dentistry Study, School of Medicine, University of Rijeka

Defects in the area of the jaw that interferes with prosthetic care are usually due to trau$\mathrm{ma}$, with consequent loss of bone and soft tissue. Also, these defects can occur after severe bone infections, or more frequent after radical surgery for malignant and benign tumors. The same etiological causes can lead to the formation of large scar on the soft tissues of the oral cavity and vestibular so that prevents the creation of correct prosthetic restorations. In the lecture, there are some cases of prosthetic care and various restorations made after surgical reconstruction of the jaw and face.

\section{ESTHETIC ZONE REHABILITATION USING IMPLANTS: PROBLEMS AND CHALLENGES \\ Damir Jelušić \\ Dental policlinic, Opatija}

Esthetic zone rehabilitation presents a challenge for every clinician whether we are talking about surgical or prosthetic part of the implant-prosthetic rehabilitation process. The key factor for every successful therapy is the pre-implant analysis and diagnostics. 3D CBCT images are of great help when choosing the correct therapy strategy. By using these images we can evaluate the bone quality and vestibular wall thickness, especially in the situations where we are evaluating the possibility of safe and predictable immediate implantation. Other important factors when planning such therapy are soft tissue condition, height and shape of gingival marginal edge, the width of the attached mucosa and the soft tissue biotype. Correct analysis of the pre mentioned factors leads to optimal treatment plan and correct sequence of surgical and prosthetic procedures. During the surgical implant pro- 
lima trodimenzionalnog pozicioniranja implantata imajući u vidu konačni protetski rad. Ispravna pozicija implantata u sve tri prostorne dimenzije apsolutni je preduvijet svake estetske rehabilitacije. Kreiranjem individualnog izlaznog profila implantata (emergency profile) stvaraju se uvjeti za nadomjestak koji će u potpunosti sličiti prirodnom zubu prethodniku. U takvim je slučajevima neophodna izrada individualne ili individualizirane protetske nadogradnje (abutment) koja će u potpunosti podupirati oblik mekih tkiva oko implantata.

\section{IMPLANTOLOGIJA U SLUČAJU VELIKOG GUBITKA KOSTI \\ Robert Cerović}

Klinika za maksilofacijalnu i oralnu kirurgiju, KBC Rijeka, Medicinski fakultet, Sveučilište u Rijeci

Augmentativna kirurgija alveolarnog grebena razvija se danas gotovo isključivo u kontekstu implantologije. Postavljanje dentalnog implantata zahtjeva zadovoljavajuću količinu kosti, i ako je nema dovoljno nema ni implantacije niti osteointegracije niti implantoprotetske rehabilitacije. Deficit kosti na alveolarnom grebenu nastaje zbog resorpcije, koja dovodi do atrofije alveolarnog grebena ili zbog različitih patoloških procesa kao što su tumori, ciste, trauma i sl. Za augmentaciju koristimo koštane transplatate koji mogu biti tvornički pripremljeni materijali različitog porjekla: ksenotransplantat- životinjskog porijekla, alotransplantat- humanog porijekla, aloplast- sintetički materijal, ali zlatni standard po kojem se sve ostale metode prosuđuju, još uvijek je autotransplantat. Donorno mjesto autotransplantata može biti intraoralno ili ekstraoralno.Važno je naglasiti da u ovoj vrsti kirurgije ne smije biti trajnih ili dugotrajnih posljedica u donornoj regiji. U slučaju manjeg nedostatka kosti, ograničene atrofije ili manjeg defekta, dovoljnu količinu kosti za transplantaciju možemo naći unutar usne šupljine. Najěešće se koriste mandibularni transplantati sa ramusa ili brade. Kod većeg nedostatka kosti uzrokovanog jakom atrofijom ili velikim defektima trebamo veću količinu kosti te moramo koristiti ekstraoralna donorna mjesta, najčesće sa kriste iliace ili kalvarije. Radi se o dobroj i sigurnoj kirurškoj metodi koja omogućava postizanje konačnog cilja kod pacijenta- implantoprotetsku rehabilitaciju. U slučaju atrofije , metoda je jednostavna i cilj se postiže uglavnom u jednoj operativnoj proceduri ,dok u slučajevima većih defekata krajnji rezultat često ovisi o motivaciji pacijenata, jer ponekad nije moguće postići dobar rezultat u samo jednoj operativnoj proceduri.

\section{ZIGOMATIČNI IMPLANTATI: PRIKAZ SLUČAJA \\ Mate Rogić \\ Klinika za maksilofacijalnu i oralnu kirurgiju, KBC Rijeka}

Zigomatične implantate je osmislio i prvi počeo upotrebljavati Per-Ingvar Branemark 1988. Koriste se u slučajevima ekstremne atrofije alveolarnog grebena gornje čeljusti $(<4 \mathrm{~mm})$, prisutnosti kontraindikacija za korištenjem koštanih graftova sa kriste ilijake, sistemnih bolesti sa atrofijom stražnjeg dijela maksile (pr.kongenitalna ektodermalna displazija, rascijepljeno nepce) te kod rekonstrukcija maksile nakon tumorske resekcije. Predstavljaju alternativu koštanim graftovima, podizanju dna sinua, osteotmijama (Le Fort I) i postavljanju implantata u pterigomaksilarnu regiju. Prednost ove tehnike je u kraćem trajanju liječenja budući da se radi o jednoj operaciji te odsutnosti morbiditeta donorske regije. Klinički manifestna upala maksilarnih sinusa predstavlja kontraindikaciju za postavljanje istih. Prijeoperacijska radiološka dijagnostika uključuje ortopantomogram, intraoralne rendgenske snimke, lateralni kraniogram te CT (CBCT). Zigomatični implantati su samonarezujući titanski implantati različitih dužina od 30 do $52,5 \mathrm{~mm}$ te s inkliniranom glavom od $45^{\circ}$. Obično se postavljaju u općoj anesteziji. Komplikacije kirurškog zahvata su rijetke (perforacija u infratemporalnu jamu odnosno dna orbite, sinusitis, hematom, oteklina, blaga do umjerena bol). U radu je opisan slučaj šezdestogodišnje bolesnice sa ekstremnom atrofijom gornjih čeljusti te nemogućnosti nošenja totalne zubne proteze. Detaljno je prikazan kirurški postupak postavljanja zigomatičnih implantata te protetska rehabilitacija.

\section{O40 ULOGA ORTODONTA U ORTOGNATSKOJ TERAPIJI SKELETNIH DEFORMITETA \\ Barbara Mady Maričić \\ Dentalna poliklinika, Rijeka}

Skladan izgled lica i lijep osmjeh važan je trenutak svakog pojedinca u poimanju sebe u svakodnevnom društvenom okruženju. Izražene skeletne anomalije i deformitete nije moguće ispraviti isključivo ortodontskom terapijom. Ortognatskom kirurgijom objedinjena je ortodontska terapija i kirurški tretman u cilju ispravljanja i dobivanja stabilne funkcijske ravnoteže zuba, čeljusti i lica. Sprega maksilofacijalnog kirurga i ortodonta s pacijentom uključuje temeljitu dijagnostiku od funkcijske i gnatometrijske do kefalometriijke analize niza rtg snimaka poput PA i LL telerendgenograma, te ortopantomograma i CT snimaka, analiza TMZ-ova, zatim planiranje terapije i tijeka terapijskih postu- cedure one should have in mind the correct three dimensional implant positioning that allows for the option prosthetic loading. The correct three-dimensional implant placement is the absolute prerequisite for every esthetic rehabilitation. When creating the individual implant emergency profile one creates conditions for natural looking prosthetic rehabilitation. In such case one must create the individual or individualized prosthetic abutment that will completely support the soft tissues surrounding the implant.

\section{IMPLANTOLOGY IN CASES OF GREAT BONE LOSS \\ Robert Cerović \\ Department of Maxillofacial and Oral Surgery, University Hospital Center \\ Rijeka, School of Medicine, University of Rijeka}

Augmentative surgery develops today almost exclusively in the context of implantology. The placement of an implant requires sufficient bone. If there is not enough bone there will be no implantation, no osseo integration, and no implant rehabilitation. When asked why we do this procedure, the response is due to deficiencies of bone, and the deficit is due bone resorption, which leads to atrophy of alveolar ridge, or because of defect that are caused by various pathological process such as tumors, cysts, trauma etc. We are using bone grafts for augmentation. These are factory- prepared biomaterials which can be xenografts- animal origin, alograft- human origin, aloplast- synthetic. They are offered in different forms and shapes: granules, blocks, gel, membranes, but the gold standard by which all other methods should be judged is autograft. Donor sites of the autograft can be in the oral cavity, or extra oral. It is important to emphasis that in this type of surgery should not be permanent or longer-lasting consequences in donor region. In cases of less bone deficiency, limited atrophy, or a smaller defect, a sufficient amount of bone for transplantation can be found in the oral cavity. I use mostly mandibular graft from the ramus or chin. For larger deficit due to severe bone atrophy or major defects we need more bones, and must take it from extra oral sites. We use grafts from iliac crest or from calvaria. This is a good and safe method that allows achieving the final goal of patient implant prosthetic rehabilitation. In the cases of atrophy the method is very simple and the goal is achieved mainly in a single operative procedure. In the case of larger defects, the final result depends often on the motivation of the patient, because sometimes is not possible to achieve a good result in only one operative procedure.

\section{ZYGOMATIC IMPLANTS: CASE STUDY}

Mate Rogić

Department of Maxillofacial and Oral Surgery, University Hospital Center Rijeka

Zygomatic implants were invented and first used by Per-Ingvar Branemark in 1988. They are used in cases of extreme atrophy of the maxilla $(<4 \mathrm{~mm})$, the presence of contraindications to the use of bone grafts from the iliac crest, systemic diseases with atrophy of the back of the maxilla (e.g. congenital ectodermal dysplasia, cleft palate), and the reconstruction of maxilla after tumor resection. They represent an alternative to bone grafts, sinus elevation, osteotomies (Le Fort I) and implant placement into pterygomaxillar region. The advantage of this technique is a shorter duration of treatment, since it is a single operation and the absence of morbidity in the donor region. Clinically manifested inflammation of the maxillary sinus is a contraindication to its implantation. Preoperative radiological diagnosis includes orthopantomogram, intraoral radiographs, lateral radiography of the skull and CT (СBCT). Zygomatic implants are self-tapping titanium implants of various lengths from 30 to $52.5 \mathrm{~mm}$, with the head inclined $45^{\circ}$. It is usually placed under general anesthesia. Complications of surgery are rare (perforations in infratemporal fossa or orbital floor, sinusitis, hematoma, swelling, mild to moderate pain). This paper describes the case of sixty year old patient with extreme atrophy of the upper jaw and the inability to carry complete dentures. It provides detailed description of the surgical procedure of applying zygomatic implants and prosthetic rehabilitation.

\section{O40 THE ROLE OF THE ORTHODONTIST IN A SKELETAL DEFORMITIES TREATMENT \\ Barbara Mady Maričić \\ Dental Policlinic, Rijeka}

The face and the beautiful smile is the part of the body that produces the greatest concern regarding physical attraction. It is the individual's focal point and the source of vocal and emotional communications with others. The severe skeletal deformities is not possible resolve with orthodontics alone. The orthognathic surgery combined the orthodontic treatment and surgical corrections to achieve stable functional equilibrium of the teeth, jaw and face. The diagnostic information gained from preoperative clinical and radiological assessment and model analysis are integrated to estabilish a treatment plan. Case reports of the congenital anomalies, skeletal deformities depending of growth and maturation 
paka što se evaluira tijekom terapije, posebice netom prije kirururškog plana koji može uključivati zahvate na čeljustima, bradi i nosu. Kroz prikaze slučajeva od kongenitalnih anomalija i skeletnih deformiteta uvjetovanih rastom i razvojem do postraumatskih slučajeva ukazati će se na važnost uske suradnje i dobrog razumijevanja maksilofacijalnog kirurga i ortodonta koja mora rezultirati osim funkcijskom ravnotežom i zadovoljstvom pacijenta.

O41 KIRURŠKO LIJEČENJE DEFORMITETA ČELJUSTI

Mate Rogić

Klinika za maksilofacijalnu i oralnu kirurgiju, KBC Rijeka

\section{O42 POMLADIVANJE LICA DERMALNIM FILERIMA}

Aleksandar Milenović

Klinika za kirurgiju lica, čeljusti i usta, KB Dubrava, Stomatološki fakultet,

Sveučilište u Zagrebu and posttraumatic cases illustrate the importance of a good team approach between the maxillofacial surgeon and orthodontist for proper diagnosis and treatment planning to achieve the results with the fulfillment of the patient's facial and dental aspirations.

\section{O41 SURGUCAL TREATMENT OF JAW DEFORMITIES} Mate Rogić

Department of Maxillofacial and Oral Surgery, University Hospital Center Rijeka

O42 FACIAL REJUVENATION USING DERMAL FILLERS

Aleksandar Milenović

Department of Maxillofacial and Oral Surgery, University Hospital Dubrava, School of Dental Medicine, University of Zagreb 